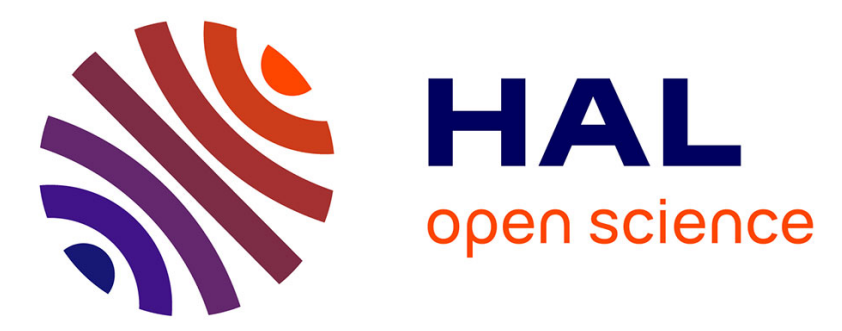

\title{
Priming effect and microbial diversity in ecosystem functioning and response to global change: a modeling approach using the SYMPHONY model
}

\author{
Nazia Perveen, Sébastien Barot, Gaël Alvarez, Katja Klumpp, Alain
}

Rapaport, Sébastien Fontaine

\section{To cite this version:}

Nazia Perveen, Sébastien Barot, Gaël Alvarez, Katja Klumpp, Alain Rapaport, et al.. Priming effect and microbial diversity in ecosystem functioning and response to global change: a modeling approach using the SYMPHONY model. Global Change Biology, 2014, 20 (4), pp.1174-1190. 10.1111/gcb.12493 . hal-00914045

\section{HAL Id: hal-00914045 \\ https://inria.hal.science/hal-00914045}

Submitted on 28 May 2020

HAL is a multi-disciplinary open access archive for the deposit and dissemination of scientific research documents, whether they are published or not. The documents may come from teaching and research institutions in France or abroad, or from public or private research centers.
L'archive ouverte pluridisciplinaire HAL, est destinée au dépôt et à la diffusion de documents scientifiques de niveau recherche, publiés ou non, émanant des établissements d'enseignement et de recherche français ou étrangers, des laboratoires publics ou privés. 


\title{
Priming effect and microbial diversity in ecosystem functioning and response to global change: a modeling approach using the SYMPHONY model
}

\author{
NAZIA PERVEEN ${ }^{1}$, SÉBASTIEN BAROT ${ }^{2}$, GAËL ALVAREZ ${ }^{1,3}$, KATJA KLUMPP ${ }^{1}$, \\ RAPHAEL MARTIN ${ }^{1}$, ALAIN RAPAPORT ${ }^{4}$, DAMIEN HERFURTH ${ }^{1,3}$, FRÉDÉRIQUE \\ LOU A U L T $^{1}$ and SÉBASTIEN FONTAINE ${ }^{1}$ \\ ${ }^{1}$ INRA, UR874 (Unité Recherche d'Ecosystème prairial), 5 Chemin de Beaulieu, 63039 Clermont-Ferrand, France, ${ }^{2} I R D$, UMR \\ (7618) BIOEMCO (Biogéochimie et Ecologie des Milieux Continentaux) Ecole Normale Supérieure, 46 rue d'Ulm, 75230, Paris, \\ France, ${ }^{3}$ Clermont Université, VetAgro Sup, BP 10448, F-6300 Clermont-Ferrand, France, ${ }^{4} U M R$ INRA/SupAgro 'MISTEA' and \\ EPI INRA/INRIA 'MODEMIC', 2, pl. Viala, 34060 Montpellier, France
}

\begin{abstract}
Integration of the priming effect (PE) in ecosystem models is crucial to better predict the consequences of global change on ecosystem carbon (C) dynamics and its feedbacks on climate. Over the last decade, many attempts have been made to model PE in soil. However, PE has not yet been incorporated into any ecosystem models. Here, we build plant/soil models to explore how PE and microbial diversity influence soil/plant interactions and ecosystem C and nitrogen $(\mathrm{N})$ dynamics in response to global change (elevated $\mathrm{CO}_{2}$ and atmospheric $\mathrm{N}$ depositions). Our results show that plant persistence, soil organic matter (SOM) accumulation, and low $\mathrm{N}$ leaching in undisturbed ecosystems relies on a fine adjustment of microbial $\mathrm{N}$ mineralization to plant $\mathrm{N}$ uptake. This adjustment can be modeled in the SYMPHONY model by considering the destruction of SOM through PE, and the interactions between two microbial functional groups: SOM decomposers and SOM builders. After estimation of parameters, SYMPHONY provided realistic predictions on forage production, soil $\mathrm{C}$ storage and $\mathrm{N}$ leaching for a permanent grassland. Consistent with recent observations, SYMPHONY predicted a $\mathrm{CO}_{2}$-induced modification of soil microbial communities leading to an intensification of SOM mineralization and a decrease in the soil C stock. SYMPHONY also indicated that atmospheric $\mathrm{N}$ deposition may promote SOM accumulation via changes in the structure and metabolic activities of microbial communities. Collectively, these results suggest that the PE and functional role of microbial diversity may be incorporated in ecosystem models with a few additional parameters, improving accuracy of predictions.
\end{abstract}

Keywords: bank functioning, $\mathrm{C}$ sequestration, $\mathrm{C} / \mathrm{N}$ coupling, nutrient cycling, nutrient mining, plant/soil interactions

Received 12 March 2013; revised version received 13 November 2013 and accepted 21 November 2013

\section{Introduction}

The priming effect $(\mathrm{PE})$ corresponds to the acceleration of mineralization of recalcitrant soil organic matter (SOM) after addition of fresh organic matter (FOM) to soil (Bingeman et al., 1953). This acceleration enhances $\mathrm{CO}_{2}$ emissions from SOM mineralization by 12 to $400 \%$ compared to soil without FOM addition (Wu et al., 1993; Cheng et al., 2003; Fontaine et al., 2004b). Strong and persistent increases in $\mathrm{CO}_{2}$ emissions may lead to a negative soil $\mathrm{C}$ balance, reducing the soil $\mathrm{C}$ stock to below initial values (Fontaine et al., 2004a,b; Dijkstra \& Cheng, 2007). Furthermore, the response of ecosystem C fluxes to global change has been shown to be controlled by PE intensity (Heimann \& Reichstein, 2008). For example, the lack of SOM accumulation in

Correspondence: Sébastien Fontaine, tel. +33 4736248 72, fax +33 4736244 57, e-mail: sebastien.fontaine@clermont.inra.fr ecosystems exposed to elevated $\mathrm{CO}_{2}$ has been attributed to microbial priming of SOM (Hoosbeek et al., 2004; Talhelm et al., 2009; Drake et al., 2011; Iversen et al., 2012). These recent advances on PE indicate the need for a revision of current models that simulate the decomposition of SOM with first-order kinetics, considering only SOM pool size and environmental factors (Jenny, 1941; McGill, 1996).

Over the last decade, many attempts have been made to model PE and its consequences for soil $\mathrm{C}$ and nitrogen $(\mathrm{N})$ cycles. It is remarkable that all these attempts have focused on building alternative models of SOM dynamics rather than integrating PE into existing models (Schimel \& Weintraub, 2003; Fontaine \& Barot, 2005; Neill \& Gignoux, 2006; Blagodatskaya et al., 2010b; Guenet et al., 2010), likely because the latter approach requires changes in the core structure of current models that are relatively complex (many SOM compartments and soil processes are modeled) (McGill, 
1996). Alternative models simulate the PE by considering one or several pools of microbial biomass that are linked to SOM decomposition rate using linear (Fontaine \& Barot, 2005; Blagodatskaya et al., 2010b) or nonlinear saturating equations (Gignoux et al., 2001; Schimel \& Weintraub, 2003). Some models also explicitly consider the stoichiometric constraints of microbial biomass (Schimel \& Weintraub, 2003; Fontaine \& Barot, 2005) and the interactions between distinct microbial functional groups to simulate the decrease in PE after supply of mineral nutrients to soil microbes (Fontaine et al., 2004b; Allison et al., 2008). These models have improved our understanding of the molecular, cellular, and microbial population-scale mechanisms at play and are able to predict PE in soils incubated with different $\mathrm{C}$ substrates and $\mathrm{N}$ availability (Neill \& Gignoux, 2006; Blagodatskaya et al., 2010b; Neill \& Guenet, 2010). However, the common missing point in all of these models is the plant compartment. The next step is to build a PE model taking into account soil/plant interactions and their feedback to $\mathrm{C}$ and $\mathrm{N}$ cycles.

Some experimental studies on PE suggest that links between plant and SOM decomposers are bidirectional. Plants stimulate SOM decomposers through deposition of energy-rich C substrates in rhizosphere (Cheng et al., 2003; Dijkstra \& Cheng, 2007; Shahzad et al., 2012), whereas stimulated SOM decomposers increase gross N mineralization (Dijkstra et al., 2009, 2011) and subsequent plant $\mathrm{N}$ uptake. However, plant supply of $\mathrm{C}$ to soil decomposers can also reduce $\mathrm{N}$ availability for plants. Indeed, certain microbial communities immobilize $\mathrm{N}$ from soil solution to maintain their $\mathrm{C} / \mathrm{N}$ ratio (Recous et al., 1995; Mary et al., 1996) because they are not able to mineralize SOM (Fontaine et al., 2003) or they prefer to absorb this readily available $\mathrm{N}$ instead of mineralizing SOM (Kuzyakov et al., 2000) which is an energy-consuming process (Fontaine et al., 2007). Part of the immobilized $\mathrm{N}$ is then sequestered in SOM over tens or hundreds of years (Martel \& Paul, 1974) before its release by microbial mineralization (Mary et al., 1996). Consequently, the availability of $\mathrm{N}$ for plants depends on complex microbial mechanisms that control the $\mathrm{N}$ release/sequestration balance in SOM.

Recent studies report an indirect control of the $\mathrm{N}$ release/sequestration balance by plant uptake of mineral N (i.e., Inselsbacher et al., 2013). For example, under elevated $\mathrm{CO}_{2}$, plants increase their $\mathrm{N}$ uptake, which in turn intensifies SOM mineralization (N release) (Carney et al., 2007; Drake et al., 2011). In contrast, a reduction in plant $\mathrm{N}$ uptake in response to plant clipping decreases SOM mineralization leading to N sequestration (Shahzad et al., 2012). These results suggest that soils function as a bank of nutrients for plants, releasing nutrients from SOM when plant $\mathrm{N}$ uptake is high and sequestering mineral nutrients when plant $\mathrm{N}$ uptake is low. As the availability of mineral $\mathrm{N}$ for microorganisms drives PE intensity and N mineralization (Fontaine et al., 2004b), it has been suggested that PE could explain this bank functioning of soils (Fontaine et al., 2011). The integration of plants in PE models is, therefore, needed to better understand the 'bank mechanism' and its consequences for ecosystem function. Moreover, as this 'bank mechanism' may be sensitive both to mineral $\mathrm{N}$ availability and to atmospheric $\mathrm{CO}_{2}$ that are currently increasing at a global scale (Barnola et al., 1983; Keeney \& Hatfield, 2008), such a model could lead to new predictions on the ecosystem response to global change.

The objectives of this modeling work were to: (1) build a plant/soil model including the PE; (2) determine the consequences of this inclusion for plant/soil interactions and ecosystem $\mathrm{C}$ and $\mathrm{N}$ dynamics; (3) parameterize the model and test its ability to predict forage production, soil $\mathrm{C}$ storage and $\mathrm{N}$ leaching in a permanent grassland; (4) explore the role of $\mathrm{PE}$ and microbial diversity on ecosystem responses to rising atmospheric $\mathrm{CO}_{2}$ and $\mathrm{N}$ depositions. To this end, a plant compartment was integrated in two existing models of SOM dynamics including the PE: one considers a single microbial type, the second considers two distinct microbial functional groups (Fontaine \& Barot, 2005). The use of these two models allowed us to test the idea that interactions between functionally distinct microbial groups control plant/microbe coexistence and ecosystem properties as crucial as SOM accumulation. Models were analyzed mathematically at steady state, through simulations and comparison with pasture observations. We emphasize that this work is an exploration of alternative mathematical formulations that can be used to integrate the PE in existing models, and does not call into question the relevance of these models.

\section{Materials and methods}

\section{Plant/soil model with a single microbial type}

The model consists of one plant compartment, three soil organic C pools and one pool of mineral N (Fig. 1a; Table 1). The plant compartment supplies the soil with a flux of fresh organic $C m_{\mathrm{p}} C_{\mathrm{p}}$ where $C_{\mathrm{p}}$ is the plant $\mathrm{C}$ and $m_{\mathrm{p}}$ is the rate of plant $C$ deposition (plant tissue turnover and root exudation). A fraction $e_{\mathrm{p}}$ of plant biomass is exported out of the ecosystem owing to herbivory or plant harvest. A fraction $r_{\mathrm{p}}$ of plant $\mathrm{C}$ is released as $\mathrm{CO}_{2}$ owing to respiration. Plants take up mineral nitrogen $\left(\varphi_{\text {up }}\right)$ and atmospheric $\mathrm{CO}_{2}\left(\varphi_{\mathrm{ph}}\right)$ to form biomass with constant $\mathrm{N}: \mathrm{C}$ ratio $(\beta)$. At each time step, the plant $\mathrm{N}$ uptake $\left(\varphi_{u p}\right)$ is determined by the maintenance of plant N/C ratio as follows: 

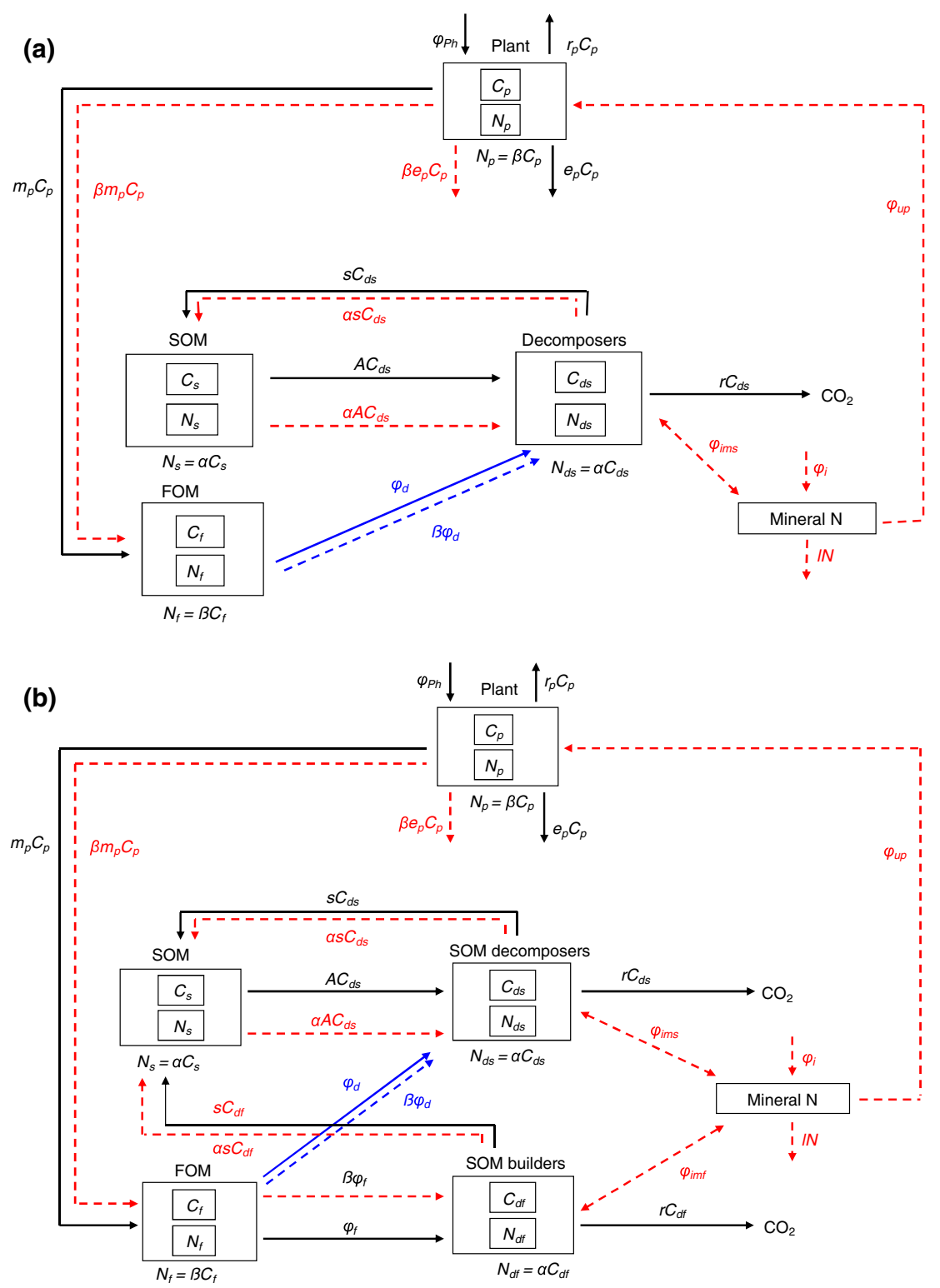

Fig. 1 Flow diagrams of the two study ecosystem models. Model 1 considers a single microbial type (a) whereas model 2 (SYMPHONY) considers two distinct microbial functional types (b). Solid arrows represent flows of $\mathrm{C}$ and dashed arrows represent flows of $\mathrm{N}$ between different compartments.

$$
\begin{gathered}
\frac{N_{\mathrm{p}}+\mathrm{d} N_{\mathrm{p}} / \mathrm{d} t}{C_{\mathrm{p}}+\mathrm{d} C_{\mathrm{p}} / \mathrm{d} t}=\beta \\
\frac{\beta C_{\mathrm{p}}+\varphi_{\mathrm{up}}-\beta C_{\mathrm{p}}\left(m_{\mathrm{p}}+e_{\mathrm{p}}\right)}{C_{\mathrm{p}}+\varphi_{\mathrm{ph}}-C_{\mathrm{p}}\left(m_{\mathrm{p}}+e_{\mathrm{p}}+r_{\mathrm{p}}\right)}=\beta \\
\varphi_{\text {up }}=\beta\left(\varphi_{\mathrm{ph}}-r_{\mathrm{p}} C_{\mathrm{p}}\right)
\end{gathered}
$$

Plant growth can be limited by $\mathrm{C}$ or N. Under C limitation, plant growth is limited by the availability of atmospheric $\mathrm{CO}_{2}$ or light. In this case, the photosynthesis flux $\left(\varphi_{\mathrm{ph}}\right)$ is expressed by the function $k C_{a}$ where $C_{a}$ is the atmospheric $C_{2}$ concentration and $k$ is the fixation rate of $C$ depending on light availability. Under $\mathrm{N}$ limitation, plant growth is limited by the availability of mineral $\mathrm{N}$. In this case, the photosynthesis flux $\left(\varphi_{\mathrm{ph}}\right)$ is limited by the absorption flux $\varphi_{\mathrm{up}}$ that is expressed as $e N$ where $e$ is $\mathrm{N}$ absorption rate of plant. Thus, according to Eqn (3), the photosynthesis flux $\varphi_{\mathrm{ph}}$ is calculated as follows:

$$
\varphi_{\mathrm{ph}}=\frac{e N}{\beta}+r_{\mathrm{p}} C_{\mathrm{p}}
$$

Liebig's law of minimum determines whether plant is $C$ or N limited:

$$
\varphi_{\mathrm{ph}}=\operatorname{Min}\left\{k C_{\mathrm{a}}, \frac{e N}{\beta}+r_{\mathrm{p}} C_{\mathrm{p}}\right\}
$$


Table 1 Model compartments, fluxes and parameters. Parameter values were estimated both from published studies and specific measurements on the two study permanent pastures located in France (altitude $1040 \mathrm{~m}$, mean annual temperature $7^{\circ} \mathrm{C}$, mean annual precipitation $1200 \mathrm{~mm})$. See section 'Materials and methods' for details of estimations. The management parameters $\left(e_{\mathrm{p}}\right.$ and $\varphi_{\mathrm{i}}$ have been determined for the intensive pasture

\begin{tabular}{|c|c|c|c|}
\hline Symbol & Definition & Value & Dimension \\
\hline \multicolumn{4}{|c|}{ Model compartments } \\
\hline$C_{\mathrm{p}}$ & Carbon stock in plant & & $\mathrm{gC} \mathrm{m} \mathrm{m}^{-2}$ \\
\hline$C_{\mathrm{f}}$ & Carbon stock in FOM & & $\mathrm{g} \mathrm{C} \mathrm{m}^{-2}$ \\
\hline$C_{\mathrm{ds}}$ & Carbon stock in SOM decomposers & & $\mathrm{g} \mathrm{C} \mathrm{m}^{-2}$ \\
\hline$C_{\mathrm{df}}$ & Carbon stock in SOM builders & & $\mathrm{g} \mathrm{C} \mathrm{m}^{-2}$ \\
\hline$N$ & Mineral nutrient stock & & $\mathrm{g} \mathrm{C} \mathrm{m}^{-2}$ \\
\hline$C_{\mathrm{s}}$ & Carbon stock in SOM & & $\mathrm{g} \mathrm{C} \mathrm{m}^{-2}$ \\
\hline \multicolumn{4}{|c|}{ Model fluxes } \\
\hline$\varphi_{\mathrm{ims}}$ & $\begin{array}{l}\mathrm{N} \text { immobilization/mineralization flux } \\
\text { induced by SOM decomposers }\end{array}$ & & $\mathrm{g} \mathrm{N} \mathrm{m}^{-2}$ day $^{-1}$ \\
\hline$\varphi_{\mathrm{imf}}$ & $\begin{array}{l}\mathrm{N} \text { immobilization/mineralization flux } \\
\text { induced by SOM builders }\end{array}$ & & $\mathrm{g} \mathrm{N} \mathrm{m}^{-2}$ day $^{-1}$ \\
\hline$\varphi_{\mathrm{d}}$ & FOM decomposition by SOM decomposers & & $\mathrm{g} \mathrm{C} \mathrm{m}^{-2}$ day $^{-1}$ \\
\hline$\varphi_{\mathrm{f}}$ & FOM decomposition by SOM builders & & $\mathrm{g} \mathrm{C} \mathrm{m}^{-2}$ day $^{-1}$ \\
\hline \multicolumn{4}{|c|}{ Model parameters } \\
\hline$A$ & Decomposer consumption rate of SOM & 0.0317917 & day $^{-1}$ \\
\hline$s$ & Decomposer production rate of SOM & 0.016906 & day $^{-1}$ \\
\hline$r$ & Decomposition respiration rate & 0.0368857 & day $^{-1}$ \\
\hline$m_{\mathrm{p}}$ & Rate of plant $\mathrm{C}$ deposition & 0.00505757 & day $^{-1}$ \\
\hline$e_{\mathrm{p}}$ & Plant export rate & $7.98799 \mathrm{e}-4$ & day $^{-1}$ \\
\hline$r_{\mathrm{p}}$ & Plant respiration rate & 0.00369772 & day $^{-1}$ \\
\hline$k$ & Plant photosynthesis rate & 0.0121216 & $\mathrm{~g} \mathrm{C} \mathrm{m}^{-2}$ day $^{-1} \mathrm{ppm}_{-\mathrm{CO}_{2}}^{-1}$ \\
\hline$\alpha$ & $\mathrm{N}: \mathrm{C}$ ratio in SOM and in decomposers & 0.0909091 & dimensionless \\
\hline$\beta$ & $\mathrm{N}: \mathrm{C}$ ratio in plant and in FOM & 0.0142857 & dimensionless \\
\hline$i$ & Immobilization rate of decomposers & 0.0110068 & day $^{-1}$ \\
\hline$l$ & $\mathrm{~N}$ leaching rate of the ecosystem & 0.00262647 & day $^{-1}$ \\
\hline$y$ & $\begin{array}{l}\text { SOM-decomposers consumption rate of } \\
\text { FOM under substrate limitation }\end{array}$ & $4.22868 \mathrm{e}-4$ & day $^{-1}$ \\
\hline$u$ & $\begin{array}{l}\text { SOM-builders consumption rate of } \\
\text { FOM under substrate limitation }\end{array}$ & 0.00929094 & day $^{-1}$ \\
\hline$e$ & Plant $\mathrm{N}$ uptake rate & 0.0289652 & day $^{-1}$ \\
\hline$C_{a}$ & Atmosphere $\mathrm{CO}_{2}$ concentration & 400 & ppm \\
\hline$\varphi_{\mathrm{i}}$ & $\mathrm{N}$ input to ecosystem & 0.0627704 & $\mathrm{~g} \mathrm{~N} \mathrm{~m}^{-2}$ day $^{-1}$ \\
\hline
\end{tabular}

Input of $\mathrm{N}$ into the ecosystem $\left(\varphi_{\mathrm{i}}\right.$, atmospheric $\mathrm{N}$ depositions and fertilization) is considered constant. $\mathrm{N}$ losses (leaching and dentrification) from ecosystem are modeled by the function $l N$ where $l$ is the $N$ loss rate.

The soil $C$ pools consist of recalcitrant organic $C\left(C_{\mathrm{s}}\right)$, fresh organic $C\left(C_{\mathrm{f}}\right)$, and decomposer $C\left(C_{\mathrm{ds}}\right)$ (Fig. 1). The N/C ratios of $C_{\mathrm{s}}$ and $C_{\mathrm{ds}}$ are assumed constant and equal to $\alpha$. The $\mathrm{N} / \mathrm{C}$ ratio of $C_{\mathrm{f}}$ is assumed to be same as that of plant $(\beta)$. Decomposers mineralize $C_{\mathrm{s}}$ and $C_{\mathrm{f}}$ together because the recalcitrant $C_{\mathrm{s}}$ is not a sufficient source of energy for decomposer needs (Fontaine \& Barot, 2005; Fontaine et al., 2007). A fraction $(r)$ of decomposer biomass is released as $\mathrm{CO}_{2}$ due to respiration and turnover. Decomposers contribute to the formation of $C_{\mathrm{s}}$ by releasing recalcitrant organic compounds (s).

Uptake or release of mineral $\mathrm{N}$ by the decomposers $\left(\varphi_{\text {ims }}\right)$ is determined by the maintenance of decomposers N/C ratio $(\alpha)$ :

$$
\begin{gathered}
\frac{N_{\mathrm{ds}}+\mathrm{d} N_{\mathrm{ds}} / \mathrm{d} t}{C_{\mathrm{ds}}+\mathrm{d} C_{\mathrm{ds}} / \mathrm{d} t}=\alpha \\
\frac{\alpha C_{\mathrm{ds}}-\varphi_{\mathrm{ims}}+\alpha A C_{\mathrm{ds}}+\beta \varphi_{\mathrm{d}}-\alpha s C_{\mathrm{ds}}}{C_{\mathrm{ds}}+A C_{\mathrm{ds}}+\varphi_{\mathrm{d}}-s C_{\mathrm{ds}}-r C_{\mathrm{ds}}}=\alpha \\
\varphi_{\text {ims }}=\alpha r C_{\mathrm{ds}}+(\beta-\alpha) \varphi_{\mathrm{d}}
\end{gathered}
$$

The immobilization/mineralization flux $\left(\varphi_{\text {ims }}\right)$ is positive in the case of net $\mathrm{N}$ mineralization and is negative in the case of net $\mathrm{N}$ immobilization.

In line with results of previous PE studies, the decomposition of $C_{\mathrm{s}}$ is considered to be limited by decomposer biomass and activity. Accordingly, the decomposition of $C_{\mathrm{s}}$ is modeled by the equation $A C_{\mathrm{ds}}$ where $A$ is the rate of SOM consumption by decomposers. The availability of $\mathrm{SOM}, C_{\mathrm{s}}$, could also limit decomposition in soils with low SOM contents (Wutzler \& Reichstein, 2008). The effect of $C_{\mathrm{s}}$ limitation on model 
predictions has been analyzed (Appendix S1), but results are not presented in the core manuscript that focuses on the role of decomposer diversity and activity. Under $C_{\mathrm{s}}$ limitations, our model predictions are similar to those commonly predicted by current models of SOM dynamics (i.e., The SOM pool has a finite steady state).

In contrast to recalcitrant soil $\mathrm{C}$, the decomposition of easily degradable fresh $\mathrm{C}$ is limited by the amount of $\mathrm{C}$ when $\mathrm{N}$ is not limiting for decomposers (Paul \& Clark, 1989). Thus, the decomposers can be either $\mathrm{C}$ or $\mathrm{N}$ limited. Under $\mathrm{C}$ limitation, the fresh $C$ decomposition flux $\varphi_{\mathrm{d}}$ is expressed by the traditional function $y C_{\mathrm{f}}$ where $\mathrm{y}$ is the decay rate of $C_{\mathrm{f}}$. Under $\mathrm{N}$ limitation, the decomposition flux $\varphi_{\mathrm{d}}$ is limited by the immobilization flux $-i N$ where $i$ is the immobilization rate. Thus, according to Eqn (8), the decomposition flux $\varphi_{\mathrm{d}}$ can be expressed as follows:

$$
\varphi_{\mathrm{d}}=\frac{i N+\alpha r C_{\mathrm{ds}}}{\alpha-\beta}
$$

Liebig's law of the minimum determines whether decomposers are $\mathrm{C}$ or $\mathrm{N}$ limited:

$$
\varphi_{\mathrm{d}}=\operatorname{Min}\left\{y C_{\mathrm{f}}, \frac{i n+\alpha r C_{\mathrm{ds}}}{\alpha-\beta}\right\}
$$

Because of the strict $\mathrm{C}-\mathrm{N}$ coupling in the compartments and fluxes, the differential equations for the model can be reduced to five independent variables:

$$
\begin{gathered}
\frac{\mathrm{d} C_{\mathrm{p}}}{\mathrm{d} t}=\varphi_{\mathrm{ph}}-C_{\mathrm{p}}\left(r_{\mathrm{p}}+m_{\mathrm{p}}+e_{\mathrm{p}}\right) \\
\frac{\mathrm{d} C_{\mathrm{f}}}{\mathrm{d} t}=m_{\mathrm{p}} C_{\mathrm{p}}-\varphi_{\mathrm{d}} \\
\frac{\mathrm{d} C_{\mathrm{ds}}}{\mathrm{d} t}=(A-s-r) C_{\mathrm{ds}}+\varphi_{\mathrm{d}} \\
\frac{\mathrm{d} N}{\mathrm{~d} t}=\varphi_{\mathrm{i}}-l N-\varphi_{\mathrm{up}}+\varphi_{\mathrm{ims}} \\
\frac{\mathrm{d} C_{s}}{\mathrm{~d} t}=(s-A) C_{\mathrm{ds}}
\end{gathered}
$$

\section{Plant/soil model with two microbial functional types}

Two microbial functional groups are distinguished in this model (called SYMPHONY hereafter in reference to the organized interactions between plant and decomposers; Fig. 1b; Table 1). As in the previous model, one group of microorganisms, called SOM decomposers $\left(C_{\mathrm{ds}}\right)$, degrades recalcitrant $\mathrm{SOM}$ by using fresh $\mathrm{C}$ as an energy source. A second group of decomposers only decomposes fresh C (Fontaine et al., 2003). This group favors SOM accumulation because it releases recalcitrant SOM compounds without mineralizing them. This group is referred to as SOM builders $\left(C_{\mathrm{df}}\right)$. Despite their contrasting roles regarding the $\mathrm{SOM}$ pool, SOM builders and SOM decomposers have similar characteristics: the two decomposers have the same $\mathrm{N} / \mathrm{C}$ ratio $(\alpha)$, rate of $\mathrm{CO}_{2}$ production $(r)$, rate of SOM production (s) and can be limited by $\mathrm{C}$ or $\mathrm{N}$. For $\mathrm{C}$ or $\mathrm{N}$ limitation of SOM builders, fresh $\mathrm{C}$ decomposition flux $\left(\varphi_{\mathrm{f}}\right)$, and mineralization/immobilization flux $\left(\varphi_{\mathrm{imf}}\right)$ were calculated with the same approach as in the previous model. The differential equations of the model read as follows:

$$
\begin{gathered}
\frac{\mathrm{d} C_{\mathrm{p}}}{\mathrm{d} t}=\varphi_{\mathrm{ph}}-C_{\mathrm{p}}\left(r_{\mathrm{p}}+m_{\mathrm{p}}+e_{\mathrm{p}}\right) \\
\frac{\mathrm{d} C_{\mathrm{f}}}{\mathrm{d} t}=m_{\mathrm{p}} C_{\mathrm{p}}-\varphi_{\mathrm{d}}-\varphi_{\mathrm{f}} \\
\frac{\mathrm{d} C_{\mathrm{df}}}{\mathrm{d} t}=\varphi_{\mathrm{f}}-(s+r) C_{\mathrm{df}} \\
\frac{\mathrm{d} C_{\mathrm{ds}}}{\mathrm{d} t}=(A-s-r) C_{\mathrm{ds}}+\varphi_{\mathrm{d}} \\
\frac{\mathrm{d} N}{\mathrm{~d} t}=\varphi_{\mathrm{i}}-l N-\varphi_{\mathrm{up}}+\varphi_{\mathrm{ims}}+\varphi_{\mathrm{imf}} \\
\frac{\mathrm{d} C_{\mathrm{s}}}{\mathrm{d} t}=(s-A) C_{\mathrm{ds}}+s C_{\mathrm{df}} \\
\varphi_{\mathrm{f}}=\operatorname{Min}\left\{u C_{\mathrm{f}}, \frac{i N+\alpha r C_{\mathrm{df}}}{\alpha-\beta}\right\} \\
\varphi_{\mathrm{imf}}=\alpha r C_{\mathrm{df}}+(\beta-\alpha) \varphi_{\mathrm{f}}
\end{gathered}
$$

where $u$ is the rate of FOM consumption by SOM builders under $\mathrm{C}$ limitation. The fluxes $\varphi_{\mathrm{d}}, \varphi_{\mathrm{ims}}, \varphi_{\mathrm{ph}}$, and $\varphi_{\mathrm{up}}$ are expressed by the same equations as in the previous model.

\section{Mathematical analysis of models at steady state}

The two models were mathematically analyzed at steady state of all model compartments (differential equations were set to zero) except the SOM pool that does not necessarily reach equilibrium (see criteria below). The feasibility of steady states was determined by studying the conditions to obtain positive values for ecosystem compartments. Moreover, the models must be able to account for the priming effect and a number of key ecosystem properties used as criteria for model evaluation:

1 The coexistence of plant and decomposers.

2 Ecosystems must be able to resist to a long-term (10 years) net nutrient output. Indeed, several long-term agro-ecological experiments (LTAE) have shown that grasslands and cultivated soils persist even when they are exposed to net nutrient outputs (biomass harvest and no fertilization) over 10 years (Kofoed \& Nemming, 1976; Dyke et al., 1983; Mattsson, 1987b; Rasmussen et al., 1998). During this period, SOM serves as a reserve of nutrients for plants allowing ecosystem persistence despite the large quantity of nutrient exported (Kofoed \& Nemming, 1976; Dyke et al., 1983; Mattsson, 1987b; Rasmussen et al., 1998). This soil process contributes to the stability of natural ecosystems because $\mathrm{N}$ inputs and $\mathrm{N}$ outputs are highly variable and can sometimes lead to a negative balance (Vitousek \& Howarth, 1991; Rasmussen et al., 1998). In our model, ecosystem resistance to net nutrient output implies that compartment values must remain positive when $\varphi_{\mathrm{i}}-l N-\beta e_{\mathrm{p}} C_{\mathrm{p}}<0$ (Fig. 1).

3 The continuous accumulation of SOM in undisturbed soils (grassland and forest soils) when there is net nutrient input to ecosystems (Syers et al., 1970; Schlesinger, 1990; Knops \& 
Tilman, 2000), i.e., there is no theoretical limit to soil C accumulation (Reichstein et al., 2009). In our model, this property implies that $\mathrm{d} C_{\mathrm{s}} / \mathrm{d} t$ must be $>0$ when $\varphi_{\mathrm{i}}-l N-$ $\beta e_{\mathrm{p}} C_{\mathrm{p}}>0$ where $\varphi_{\mathrm{i}}$ is the $\mathrm{N}$ input to ecosystem, $l N$ is the $\mathrm{N}$ leaching and $\beta e_{\mathrm{p}} C_{\mathrm{p}}$ is the $\mathrm{N}$ output from the ecosystem due to plant exports (herbivore consumption, plant harvest).

4 Eventual steady state for SOM pool, especially in agricultural systems where $\mathrm{N}$ inputs balance $\mathrm{N}$ outputs (Johnston et al., 2009). In our model, this property implies that $\mathrm{d} C_{\mathrm{s}} / \mathrm{d} t=0$ in some conditions.

\section{Model parameterization}

The model including the two microbial populations SYMPHONY was the sole model capable of accounting for all above criteria. Therefore, SYMPHONY was parameterized to (1) study the mechanistic basis of the bank functioning of soils, (2) simulate the compartments and fluxes of study grassland, and (3) predict the grassland response to rising atmospheric $\mathrm{CO}_{2}$ and $\mathrm{N}$ inputs to ecosystem (fertilization, atmospheric $\mathrm{N}$ depositions).

Model parameters were estimated from both published studies and specific measurements made at a studied experimental site (Table 1). The site is a temperate permanent grassland located at $1040 \mathrm{~m}$ in France (Laqueuille, $45^{\circ} 38^{\prime} \mathrm{N}, 2^{\circ} 44^{\prime} \mathrm{E}$ ). Mean annual precipitation and temperature are $1200 \mathrm{~mm}$ and $7{ }^{\circ} \mathrm{C}$, respectively. The site is divided into two adjacent pastures grazed by heifers but at different intensities. Intensive pasture is adjusted to a mean stocking rate of 1 living stock unit (LSU) ha ${ }^{-1} \mathrm{yr}^{-1}$ and is fertilized with $190 \mathrm{~kg} \mathrm{~N} \mathrm{ha}^{-1} \mathrm{yr}^{-1}$ (ammonium nitrate). Extensive pasture was adjusted to mean stocking rate of $0.5 \mathrm{LSU}_{\mathrm{ha}}^{-1} \mathrm{yr}^{-1}$ and was not fertilized. For more details, see Allard et al. (2007).

Decomposer consumption rate of SOM $A$ was estimated following Fontaine et al. (2011) who quantified biomass and activity of cellulolytic fungi carrying out PE. Turnover of decomposers $s+r$ was calculated from the decay rate of cellulolytic fungi after exhaustion of fresh C (Fontaine et al., 2007, 2011). Decomposer production rate of SOM $s$ was estimated by assuming that $30 \%$ of the consumed fresh $\mathrm{C}$ by decomposers is humified in SOM (Hénin \& Dupuis, 1945; Kirkby et al., 2013). The fraction of decomposer biomass released as $\mathrm{CO}_{2} r$ was given by the difference between $s+r$ and $s$. The rate of fresh $\mathrm{C}$ consumption by SOM decomposers $y$ and the rate of fresh $\mathrm{C}$ consumption by SOM builders $u$ were determined by constraining SYMPHONY to compartments and fluxes of study grassland. The N/C ratio of FOM and SOM, respectively, $\beta$ and $\alpha$, was estimated by measuring the $\mathrm{C} / \mathrm{N}$ ratio of plant roots and total soil organic matter of the studied site. Plant photosynthesis rate under $C$ limitation $k$ was estimated by measuring biomass accumulation in the intensive pasture where plants were considered to be limited by $\mathrm{C}$ due to $\mathrm{N}$ fertilization and more frequent grazing (Allard et al., 2007; Klumpp et al., 2011). Plant $\mathrm{N}$ uptake under $\mathrm{N}$ limitation $e$ was estimated by measuring biomass accumulation in the extensive pasture where plants were considered to be mainly $\mathrm{N}$-limited. The immobilization rate of mineral $\mathrm{N}$ by decomposers $i$ was estimated by considering a ratio of 0.38 between rates of microbial immobilization $i$ and plant $\mathrm{N}$ uptake $e$ (Recous et al., 1996). Plant respiration rate $r_{\mathrm{p}}$ was estimated by assuming that $40 \%$ of fixed $\mathrm{C}$ is released as $\mathrm{CO}_{2}$ (Nguyen, 2003; Balesdent et al., 2011). The rate of plant $C$ deposition $m_{\mathrm{p}}$ was estimated from Picon-Cochard et al. (2012). Leaching rate $l$ was estimated from Simon et al. (1996). Carbon dioxide $\left(\mathrm{CO}_{2}\right)$ concentration $C_{\mathrm{a}}$ was initially fixed to ambient level (400 ppm). A matrix analysis of parameterized model was made in order to check its feasibility and stability (Appendix S3). For this analysis, the management parameters were taken from the intensive pasture.

\section{Simulation of studied grassland functioning}

To test the capacity of SYMPHONY to simulate the functioning of our study grassland, we constrained the model with the management of the intensive pasture (parameter $e_{\mathrm{p}}$ and $\varphi_{\mathrm{i}}$ Table 1) and compared predicted compartment sizes and fluxes with observations (Table 4). The deviation between modeled (MV) and observed (OV) values was minimized by fitting microbial parameters $u$ and $y$ using Berkeley Madonna. To give the same weight to each variable during the fitting, the relative mean deviation (RD) was calculated as follows: $\mathrm{RD}=\sum_{i=1}^{n}\left(\left(\mathrm{MO}_{i}-\mathrm{OV}_{i}\right) /\left(\mathrm{OV}_{i} * n\right)\right)$ where $n$ is the number of study variables.

Plant export rate $e_{\mathrm{p}}$ was calculated from the stocking rate (approx. $1 \mathrm{LSU} \mathrm{ha} \mathrm{hr}^{-1} \mathrm{yr}^{-1}$ ) and by assuming an uptake of $12 \mathrm{~kg} \mathrm{DM}$ day $^{-1} \mathrm{LSU}^{-1}$. The total $\mathrm{N}$ inputs to this ecosystem (fertilization, animal excretion, biological fixation, and $\mathrm{N}$ depositions) were estimated by calculating a complete $\mathrm{N}$ balance of the intensive pasture. Given that our model does not explicitly consider animal excretion and biological fixation, we assumed that these inputs supplied the pool of mineral $\mathrm{N}$ through $\varphi_{\mathrm{i}}$. The flux $\varphi_{\mathrm{i}}$ was estimated to $0.063 \mathrm{~g} \mathrm{~N} \mathrm{~m}^{-2}$ day $^{-1}$.

Mean annual compartment sizes and ecosystem fluxes were quantified in the intensive pasture over the period 2003-2008 and by considering a soil depth of $0-60 \mathrm{~cm}$ (Table 4). Plant C stock $\left(C_{\mathrm{p}}\right)$ was estimated from root and shoot biomass and its $\mathrm{C}$ content. Fresh organic $\mathrm{C}$ stock $\left(C_{\mathrm{f}}\right)$ was estimated by quantifying particulate organic matter (POM $>200 \mu \mathrm{m}$ ) (Loiseau \& Soussana, 1999) and its $C$ content. Soil mineral $N(N)$ was quantified after extraction with $\mathrm{KCl}$. Soil $\mathrm{C}$ stock $\left(C_{\mathrm{s}}\right)$ was estimated from total $\mathrm{C}$ and bulk density. Net carbon flux to soil $\left(\mathrm{d} C_{\mathrm{s}} / \mathrm{d} t\right)$ was estimated by the eddy covariance technique combined with specific greenhouse gas measurements such as methane emissions (Klumpp et al., 2011). Flux of N leaching (lN) was obtained from Simon et al. (1996). Plant carbon exports $\left(e_{\mathrm{p}} C_{\mathrm{p}}\right)$ by heifers were estimated assuming an uptake of $12 \mathrm{~kg} \mathrm{DM}$ day $^{-1}$ per LSU and $42 \%$ carbon content in forage.

\section{Study of the mechanistic basis of the bank functioning}

Nitrogen inputs to the intensive pasture were drastically reduced (current inputs divided by 6) to impose a net nutrient output $\left(\varphi_{\mathrm{i}}-l N-\beta e_{\mathrm{p}} C_{\mathrm{p}}<0\right)$ on the ecosystem that is currently subjected to a net nutrient input $\left(\varphi_{\mathrm{i}}-l N-\beta e_{\mathrm{p}} C_{\mathrm{p}}>0\right)$. The response of ecosystem compartments an fluxes to these 
two ecosystem $\mathrm{N}$ balances was determined to analyze the soil capacity to release or sequester $\mathrm{N}$ (bank functioning).

\section{Grassland response to rising atmospheric $\mathrm{CO}_{2}$ and $\mathrm{N}$} depositions: SYMPHONY predictions

To study ecosystem responses to elevated $\mathrm{CO}_{2}$ or $\mathrm{N}$ deposition, $\mathrm{CO}_{2}$ concentration was increased by $40 \%$ (from 400 to $560 \mathrm{ppm}$ ), and $\mathrm{N}$ input to ecosystem was increased by $13 \%$ (from 0.06 to $0.07 \mathrm{~g} \mathrm{~N} \mathrm{~m}^{-2}$ day $\left.^{-1}\right)$. The effect of $\mathrm{CO}_{2}\left(C_{\mathrm{a}}\right)$ and $\mathrm{N}$ input to ecosystem $\left(\varphi_{\mathrm{i}}\right)$ on soil $\mathrm{C}$ storage $\left(\mathrm{d} C_{\mathrm{s}} / \mathrm{d} t\right)$ was also studied mathematically at steady state to verify the generality of model predictions.

\section{Results}

Plant/soil model with a single microbial type

Decomposers and plants can be limited either by $\mathrm{N}$ or C. Four scenarios must thus be considered. For clarity, the results are summarized into two groups of scenarios that are interpreted similarly. The equations for these scenarios at steady state are given in Table 2 .

Scenarios 1 and 2: decomposers are $N$-limited and plants are $C$ or $N$ limited. All compartments have finite steady states except SOM and FOM (Table 2). The SOM and FOM compartments reach steady states under particular conditions depending on model parameters and $\mathrm{N}$ inputs to the ecosystem (Eqns $\left(\mathrm{d}_{\mathrm{f}} / \mathrm{d} t\right)^{*}$ and $\left(\mathrm{dC}_{\mathrm{s}} / \mathrm{d} t\right)^{*}$, Table 2). Decomposer biomass (Eqn $C_{\mathrm{ds}^{\prime}}^{*}$ Table 2) and thus SOM mineralization depends on the availability of mineral $\mathrm{N}$ rather than fresh $\mathrm{C}$, signifying these scenarios do not simulate priming effect (PE). Moreover, decomposers immobilize $\mathrm{N}\left(\varphi_{\text {ims }}=-i \mathrm{~N}\right.$ when decomposers are $\mathrm{N}$-limited) implying that whole plant $\mathrm{N}$ uptake ( $\varphi_{\text {up }}$ in Eqns $N^{*}$, Table 2 ) must rely on $N$ inputs to the ecosystem $\left(\varphi_{\mathrm{i}}\right)$. However, this is not realistic because $\mathrm{N}$ inputs to ecosystems are commonly very low compared with plant N uptake (Mattsson, 1987a; Vitousek \& Howarth, 1991; Rasmussen et al., 1998).

Table 2 Steady states for model 1. Plants and decomposers can be limited by C or N leading to four possible scenarios

\begin{tabular}{|c|c|c|}
\hline \multirow{4}{*}{ 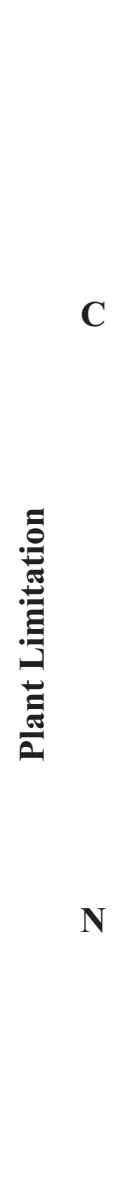 } & Decomposers Limitation & \\
\hline & $\mathbf{N}$ & $\mathbf{C}$ \\
\hline & $\begin{array}{l}\text { Scenario 1 } \\
C_{p}^{*}=\frac{k C_{a}}{m_{p}+r_{p}+e_{p}} \\
\left(\frac{d C_{f}}{d t}\right)^{*}=m_{p} C_{p}^{*}-\frac{i N^{*}}{\alpha-\beta}\left(1-\frac{\alpha r}{\alpha(s-A)-\beta(s+r-A)}\right) \\
C_{d s}^{*}=\frac{i N^{*}}{\alpha(s-A)-\beta(s+r-A)} \\
N^{*}=\frac{\varphi_{i}-\varphi_{u p}}{l+i} \\
\left(\frac{d C s}{d t}\right)^{*}=(s-A) C_{d s}^{*}\end{array}$ & $\begin{array}{l}\text { Scenario 3 } \\
C_{p}^{*}=\frac{k C_{a}}{m_{p}+r_{p}+e_{p}} \\
C_{f}^{*}=\frac{m_{p} C_{p}^{*}}{y} \\
C_{d s}^{*}=\frac{m_{p} C_{p}^{*}}{(s+r-A)} \\
N^{*}=\frac{\varphi_{i}-\beta e_{p} C_{p}^{*}-\alpha(s-A) C_{d s}^{*}}{l} \\
\left(\frac{d C s}{d t}\right)^{*}=(s-A) C_{d s}^{*}\end{array}$ \\
\hline & $\begin{array}{l}\text { Scenario } 2 \\
C_{p}^{*}=\frac{e N^{*}}{\beta\left(m_{p}+e_{p}\right)} \\
\left(\frac{d C_{f}}{d t}\right)^{*}=m_{p} C_{p}^{*}-\frac{i N^{*}}{\alpha-\beta}\left(1-\frac{\alpha r}{\alpha(s-A)-\beta(s+r-A)}\right) \\
C_{d s}^{*}=\frac{i N^{*}}{\alpha(s-A)-\beta(s+r-A)} \\
N^{*}=\frac{\varphi_{i}-\varphi_{u p}}{l+i} \\
\left(\frac{d C s}{d t}\right)^{*}=(s-A) C_{d s}^{*}\end{array}$ & $\begin{array}{l}\text { Scenario } 4 \\
C_{p}^{*}=\frac{e N^{*}}{\beta\left(m_{p}+e_{p}\right)} \\
C_{f}^{*}=\frac{m_{p} C_{p}^{*}}{y} \\
C_{d s}^{*}=\frac{m_{p} C_{p}^{*}}{(s+r-A)} \\
N^{*}=\frac{\varphi_{i}-\beta e_{p} C_{p}^{*}-\alpha(s-A) C_{d s}^{*}}{l} \\
\left(\frac{d C s}{d t}\right)^{*}=(s-A) C_{d s}^{*}\end{array}$ \\
\hline
\end{tabular}


Under these scenarios, the ecosystem is not able to resist a long-term net nutrient output (criteria 2 of model evaluation).

Scenarios 3 and 4: decomposers are C-limited and plants are $C$ - or N-limited. All compartments have finite steady states except SOM (Table 2). Decomposer biomass (Eqn $C_{\mathrm{ds}^{\prime}}^{*}$, Table 2) and SOM mineralization depend on fresh $C$ availability, signifying these two scenarios allow simulating PE. Direction of SOM change (increase or decrease) only depends on microbial parameters $s$ and $A$ (Eqn $\left(\mathrm{d} C_{\mathrm{s}} / \mathrm{d} t\right)^{*}$, Table 2). To account for the accumulation of SOM in ecosystems (criteria 3) the condition $s>A$ is imposed in these scenarios. This SOM accumulation implies a sequestration of $\mathrm{N}$ leading to a continuous removal of $\mathrm{N}$ from the mineral pool (Eqn $N^{*}$, Table 2). Decomposers can mineralize or immobilize $\mathrm{N}$. This immobilization/mineralization flux is determined by Eqn (8) that can be reorganized as follows:

$$
\varphi_{\text {ims }}=\beta m_{\mathrm{p}} C_{\mathrm{p}}^{*}-\alpha(s-A) C_{\mathrm{ds}}^{*}
$$

Decomposers mineralize $\mathrm{N}$ if the amount of $\mathrm{N}$ acquired through plant litter deposition $\left(\beta m_{\mathrm{p}} C_{\mathrm{p}}^{*}\right)$ is higher than the amount of $\mathrm{N}$ sequestered in the SOM pool ( $s>A$ to fulfill criteria 3). This equation also shows that, in the case of $\mathrm{N}$ mineralization, the amount of $\mathrm{N}$ mineralized by decomposers is always lower than the amount of $\mathrm{N}$ lost by the plant through litter deposition because part of litter $\mathrm{N}$ is sequestered in SOM. Moreover, there are several $\mathrm{N}$ outputs from ecosystems (plant harvest, $\mathrm{N}$ leaching). Under these conditions, the model predicts that the maintenance of ecosystem compartments requires that $\mathrm{N}$ inputs to the ecosystem always compensate plant $\mathrm{N}$ exports, $\mathrm{N}$ leaching and $\mathrm{N}$ sequestration in $\operatorname{SOM}\left(\varphi_{\mathrm{i}}=\beta e_{\mathrm{p}} C_{\mathrm{p}}^{*}+l N^{*}+\alpha(s-A) C_{\mathrm{ds}}^{*}\right.$, Eqn $N^{*}$, Table 2). Thus, the ecosystem is not able to resist a longterm net nutrient output (criteria 2 of model evaluation).

It is worth mentioning that when the criteria 3 (SOM accumulation) is not respected $(s<A)$, microbial $\mathrm{N}$ mineralization can compensate ecosystem $\mathrm{N}$ losses allowing ecosystem persistence (Eqn $N^{*}$, Table 2). However, the model predicts a continuous decrease in SOM pool until its exhaustion, which is unrealistic.

We conclude that the plant/soil model with one microbial type cannot account for ecosystem resistance to a long-term net nutrient output and the SOM accumulation in ecosystems simultaneously (criteria 2 and 3).

Plant/soil model with two microbial functional types (SYMPHONY)

Inclusion of a second microbial type that can either be $\mathrm{N}$ or $\mathrm{C}$ limited leads to eight possible scenarios.
Scenarios 1 and 2: The two decomposers are N-limited and plants are $\mathrm{C}$ - or $\mathrm{N}$-limited. Although the two decomposer types are taken into account, results are qualitatively similar to those of the model with one decomposer type limited by $\mathrm{N}$ (plant limited by Cor $\mathrm{N}$, scenarios 1 and 2): the two decomposers immobilize $\mathrm{N}$ implying that whole-plant $\mathrm{N}$ uptake ( $\varphi_{\text {up }}$ in Eqn $N^{*}$, Table 3) must rely on $\mathrm{N}$ supply to ecosystems $\left(\varphi_{\mathrm{i}}\right)$, which is not realistic.

Scenarios 3 and 4: The two decomposers are C-limited and plants are $\mathrm{C}$ - or $\mathrm{N}$-limited. Results are qualitatively similar to those of the model with one decomposer type limited by C (plants limited by C or N, scenarios 3 \& 4): the SOM pool continuously increases or decreases depending only on microbial parameters $s$ and $A$ (Eqn $\left(\mathrm{d} C_{\mathrm{s}} / \mathrm{d} t\right)^{*}$, Table 3$)$. When criteria 3 (SOM accumulation) is fulfilled, the maintenance of ecosystem compartments requires that $\mathrm{N}$ inputs to the ecosystem always compensate plant $\mathrm{N}$ exports, $\mathrm{N}$ leaching and $\mathrm{N}$ sequestration in SOM $\left(\varphi_{\mathrm{i}}=\beta e_{\mathrm{p}} C_{\mathrm{p}}^{*}+l N^{*}+\alpha(s-A) C_{\mathrm{ds}}^{*}+s C_{\mathrm{df}}^{*}\right.$ Eqn $N^{*}$, Table 3), which is not realistic.

Scenarios 5 and 6: SOM decomposers are N-limited, SOM builders are C-limited and plants are C- or N-limited. Biomass of SOM decomposers (Eqn $C_{\mathrm{ds}^{\prime}}^{*}$, Table 3) and thus $\mathrm{SOM}$ mineralization depend on the availability of mineral $\mathrm{N}$ rather than fresh $\mathrm{C}$, signifying these scenarios do not simulate the PE. The immobilization/mineralization flux induced by SOM builders is determined by Eqn (23) that can be reorganized as:

$$
\varphi_{\mathrm{imf}}=\beta \varphi_{\mathrm{f}}-\alpha \mathrm{s} C_{\mathrm{df}}^{*}
$$

This equation indicates that SOM builders only release a part of plant litter $\mathrm{N}$ that they decompose $\left(\beta \varphi_{\mathrm{f}}\right)$ the remainder being stored in SOM $\left(\alpha \mathrm{SC}_{\mathrm{df}}^{*}\right)$. Moreover, due to their $\mathrm{N}$ limitation, SOM decomposers immobilize mineral $\mathrm{N}\left(\varphi_{\text {ims }}=-i N\right)$. Under these conditions, the maintenance of ecosystem compartments requires that $\mathrm{N}$ inputs to the ecosystem always compensate plant $\mathrm{N}$ exports, $\mathrm{N}$ leaching and $\mathrm{N}$ sequestration in SOM (Eqn $N^{*}$, Table 3). Thus, the ecosystem is not able to resist to a long-term net nutrient output, which is unrealistic (criteria 2 of model evaluation).

Scenarios 7 and 8: SOM decomposers are C-limited, SOM builders are $\mathrm{N}$-limited and plants are $\mathrm{C}$ - or $\mathrm{N}$-limited. All compartments have finite steady states except the SOM pool that can reach infinity or steady state (Table 3). Biomass of SOM decomposers (Eqn $C_{\mathrm{ds}}^{*}$, Table 3) and SOM mineralization depends on fresh $\mathrm{C}$ availability, signifying that these two scenarios allow simulating the PE. As SOM decomposers compete for fresh C- with $\mathrm{N}$-limited SOM builders, the intensity of PE depends 
PRIMING EFFECT IN ECOSYSTEM FUNCTIONING 9

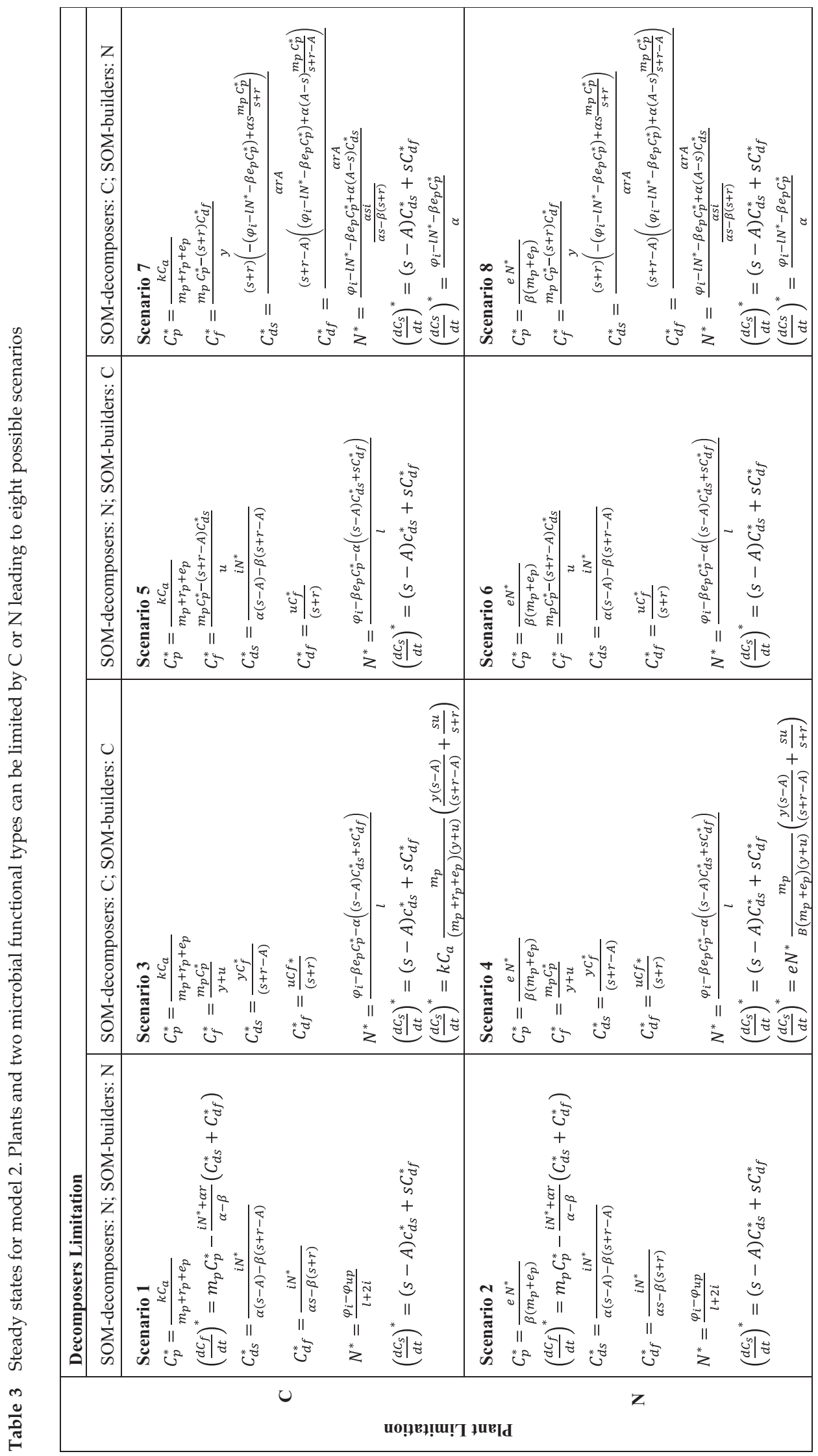


on microbial interactions as observed in recent laboratory studies (Nottingham et al., 2009; Pascault et al., 2013). Due to their N limitation, SOM builders immobilize $\mathrm{N}$ and sequester it in SOM. In contrast, SOM decomposers mineralize $\mathrm{N}$. This mineralization flux can be expressed as:

$$
\varphi_{\mathrm{ims}}=\beta \varphi_{\mathrm{d}}-\alpha(s-A) C_{\mathrm{ds}}^{*}
$$

which indicates that SOM decomposers release $\mathrm{N}$ from plant litter they decompose $\left(\beta \varphi_{\mathrm{d}}\right)$ and from the SOM pool if $s<A$, which is one condition of model feasibility (see paragraph on model feasibility below).

Ecosystem functioning in these two scenarios is notable because it can simultaneously account for ecosystem resistance to a long-term net $\mathrm{N}$ output (criteria 2) and the long-term SOM accumulation when there is net $\mathrm{N}$ input to ecosystem (criteria 3). These two key ecosystem properties are explained by the inclusion of PE and the interaction between SOM decomposers and SOM builders. A net $\mathrm{N}$ input to the ecosystem $\left(\varphi_{\mathrm{i}}-l N^{*}-\beta e_{\mathrm{p}} C_{\mathrm{p}}^{*}>0\right)$ increases $\mathrm{N}$ availability and biomass of N-limited SOM builders (Fig. 3; Table 3). As the two decomposers are in competition for fresh $\mathrm{C}$, an increase in biomass of SOM builders decreases the biomass of SOM decomposers (Fig. 3; Table 3). As a result, the SOM pool increases leading to $\mathrm{N}$ sequestration. This $\mathrm{N}$ sequestration is maintained as long as there is net $\mathrm{N}$ input to the ecosystem (Unlimited capacity of soil to accumulate SOM). When there is a net $\mathrm{N}$ output from an ecosystem $\left(\varphi_{\mathrm{i}}-l N^{*}-\beta e_{\mathrm{p}} C_{\mathrm{p}}^{*}<0\right)$, biomass of SOM builders decreases while biomass of SOM decomposers increases resulting in destruction of SOM and release of mineral N (Fig. 3; Table 3). Thus, the soil functions as a bank of nutrients by storing mineral nutrients when they are in excess in solution and by releasing nutrients from SOM when they are in low concentration and could threaten plant persistence (Fig. 3). Finally, the model predicts that the SOM pool reaches a steady state (criteria 4) when ecosystem $\mathrm{N}$ inputs balance $\mathrm{N}$ outputs.

The model guarantees plant-decomposer coexistence (criteria 1) under some conditions of feasibility. For $C_{\mathrm{df}}^{*}>0$ (Table 3 ), net $\mathrm{N}$ output from ecosystem must not exceed the term $\alpha(A-s) m_{\mathrm{p}} C_{\mathrm{p}}^{*} /(s+r-A)$. The term $m_{\mathrm{p}} C_{\mathrm{p}}^{*} /(s+r-A)$ is the maximum biomass of SOM decomposers (all the fresh $\mathrm{C}$ is taken up by SOM decomposers) and $\alpha(A-s)$ is the rate of release of $\mathrm{N}$ by SOM decomposers (with $A>s$ ). Thus, the ecosystem persists if net $\mathrm{N}$ output from the ecosystem does not exceed the maximum capacity of SOM decomposers to release $\mathrm{N}$ from SOM. For $C_{\mathrm{ds}}^{*}>0$ (Table 3), net $\mathrm{N}$ input to the ecosystem must not exceed the term $\left(\alpha s m_{\mathrm{p}} C_{\mathrm{p}}^{*} / s+r\right)$ that corresponds to the maximum capacity of SOM-builders to sequester $\mathrm{N}$ in SOM. If this condition is not met, the mineral $\mathrm{N}$ pool increases, SOM builders become $\mathrm{C}$-limited (the model switches to scenarios 3 and 4) and excess of $\mathrm{N}$ is leached (data not shown). Another condition of feasibility is that the N/C ratio of FOM must be sufficiently lower than that of decomposers (for $N^{*}>0, \alpha s-\beta(s+r$ ) must be $>0$ implying that $\alpha$ must be $\gg \beta$, Table 3 ). Otherwise, SOM builders are no longer $\mathrm{N}$-limited. This $\mathrm{N}$ limitation of SOM builders is supported by many studies showing an immobilization of $\mathrm{N}$ by microorganisms specialized in fresh C decomposition (Recous et al., 1995; Mary et al., 1996). Finally, C loss from SOM decomposers due to their turnover must be higher than their $\mathrm{C}$ uptake from SOM (For $C_{\mathrm{df}}^{*}>0, s+r-A$ must be $>0$, Table 3 ). This condition is supported by several studies (Fontaine et al., 2007, 2011) showing that the energy required to solubilize SOM compounds (i.e., production of extracellular enzymes) is higher than the energy supplied by the respiration of these catabolites. Collectively, these results suggest that the conditions of plantdecomposer coexistence are realistic. Therefore, the model in these two scenarios meets the four evaluation criteria we chose.

Plants can be C-limited (scenario 7) or N-limited (scenario 8) depending on the relative availability of $\mathrm{C}$ $\left(\mathrm{CO}_{2}+\right.$ light) and $\mathrm{N}$ (mineral $\left.\mathrm{N}\right)$. The conditions of switch between scenarios 7 and 8 are presented in Appendix S2. Shortly, when $\varphi_{\mathrm{i}}$ increases, mineral $\mathrm{N}$ also increases and plants tend to become C-limited (scenario 7). In contrast, when $\mathrm{N}$ leaching ( $l$ ) increases, mineral $\mathrm{N}$ decreases and plants tend to become $\mathrm{N}$-limited (scenario 8).

\section{Simulation of studied grassland functioning}

The mean annual plant biomass of the studied permanent grassland represented $525 \pm 107 \mathrm{~g} \mathrm{C} \mathrm{m}^{-2}$ (Table 4). The continuous supply of fresh plant $C$ led to the building of a large compartment of fresh $\mathrm{C}$ representing $635 \pm 129 \mathrm{~g} \mathrm{C} \mathrm{m}^{-2}$. The amount of $\mathrm{N}$ present in mineral compartment was low compared with plant and fresh organic matter compartments, which is typical of undisturbed ecosystems (e.g., grasslands and forests). Despite the high $\mathrm{N}$ input to this ecosystem $\left(0.063 \mathrm{~g} \mathrm{~N} \mathrm{~m}^{-2}\right.$ day $\left.^{-1}\right)$, the $\mathrm{N}$ leaching was low $\left(0.0055 \pm 0.0047 \mathrm{~g} \mathrm{~N} \mathrm{~m}^{-2} \mathrm{day}^{-1}\right)$ representing $9 \%$ of total ecosystem $\mathrm{N}$ input. The low rate of $\mathrm{N}$ leaching is a characteristic of undisturbed grassland ecosystems compared with cultivated soils (Simon et al., 1996; Lord et al., 2002). The eddy covariance measurements showed a continuous net $C$ storage of $0.57 \pm 0.40 \mathrm{~g} \mathrm{C} \mathrm{m}^{-2}$ day $^{-1}$ by this grassland. This result concurs with other studies (Syers et al., 1970; Schlesinger, 1990; Knops \& Tilman, 2000; Sanderman 
Table 4 Observed and predicted values of plant $C\left(C_{\mathrm{p}}\right)$, fresh organic $\mathrm{C}\left(C_{\mathrm{f}}\right)$, mineral $\mathrm{N}(N)$, plant harvest $\left(e_{\mathrm{p}} C_{\mathrm{p}}\right)$, $\mathrm{N}$ leaching $(l N)$ and net soil $C$ storage $\left(\mathrm{d} C_{\mathrm{s}} / \mathrm{d} t\right)$. Percentage deviation for each variable was calculated as (modeled - observed)/observed. Observed variables are mean values obtained in the study intensive pasture located in France (altitude $1040 \mathrm{~m}$, mean annual temperature $7{ }^{\circ} \mathrm{C}$, mean annual precipitation $1200 \mathrm{~mm}$ ) over the period 2003-2008. The standard deviation (SD) represents the interannual variability. See section 'Materials and methods' for details of measurements

\begin{tabular}{llcrr}
\hline Symbol & Unit & Observed value \pm SD & Predicted value & Deviation (\%) \\
\hline$C_{\mathrm{p}}$ & $\mathrm{g} \mathrm{C} \mathrm{m}^{-2}$ & $525 \pm 107$ & 507.49 & 3.3 \\
$C_{\mathrm{f}}$ & $\mathrm{g} \mathrm{C} \mathrm{m}^{-2}$ & $635 \pm 129$ & 634.99 & 0.0 \\
$N$ & $\mathrm{~g} \mathrm{~N} \mathrm{~m}^{-2}$ & $2.09 \pm 0.68$ & 2.98 & 43.0 \\
$e_{\mathrm{p}} C_{\mathrm{p}}$ & $\mathrm{g} \mathrm{C} \mathrm{m}^{-2} \mathrm{day}^{-1}$ & $0.42 \pm 0.04$ & 0.405385 & 3.3 \\
$\ln$ & $\mathrm{g} \mathrm{N} \mathrm{m}^{-2} \mathrm{day}^{-1}$ & $0.0055 \pm 0.0047$ & 0.0078342 & 0.540594 \\
$\mathrm{~d} C_{\mathrm{s}}$ & $\mathrm{g} \mathrm{C} \mathrm{m}^{-2}$ day $^{-1}$ & $0.57 \pm 0.40$ & & 5.5 \\
Mean deviation for all variables & & & 16.4 \\
\hline
\end{tabular}

et al., 2003) suggesting that permanent grasslands can continuously accumulate organic $C$ in soil without any apparent limit of accumulation.

SYMPHONY was able to simulate plant biomass $\left(C_{\mathrm{p}}\right)$, fresh organic $C\left(C_{\mathrm{f}}\right)$, mineral $\mathrm{N}(\mathrm{N})$, forage production $\left(e_{\mathrm{p}} C_{\mathrm{p}}\right), \mathrm{N}$ leaching $(l N)$ and ecosystem $\mathrm{C}$ storage $\left(\mathrm{d} C_{\mathrm{s}} / \mathrm{d} t\right)$ with only $16.4 \%$ mean deviation compared with observed values (Table 4 ). The model simulations of $C_{\mathrm{p}}, C_{\mathrm{f}}, e_{\mathrm{p}} C_{\mathrm{p}}$, and $\mathrm{d} C_{\mathrm{s}} / \mathrm{d} t$ were particularly accurate with deviations $<6 \%$ compared to observed values. The mineral $\mathrm{N}$ pool and $\mathrm{N}$ leaching were less satisfactory with $43 \%$ deviation between observed and simulated values. However, this deviation was within the range of interannual variability observed for these variables (Table 4). Moreover, the amount of $\mathrm{N}$ in play in these variables was low compared to other ecosystem variables such as $\mathrm{N}$ in plant biomass and harvest.

Model simulations showed that the parameterized model had stable steady state (Figs 2 and 3, model compartments do not vary with time). The matrix analysis of parameterized SYMPHONY (Appendix S3) indicated that the model had only one stable steady state corresponding to scenario 7 meaning that plant is limited by C, SOM builders limited by $\mathrm{N}$ and SOM decomposers limited by $\mathrm{C}$. The $\mathrm{C}$ limitation of plants is explained by the relative high $\mathrm{N}$ input to this intensive fertilized pasture $\left(0.063 \mathrm{~g} \mathrm{~N} \mathrm{~m}^{-2} \mathrm{day}^{-1}\right.$ or $\left.230 \mathrm{~kg} \mathrm{~N} \mathrm{ha}^{-1} \mathrm{yr}^{-1}\right)$.

\section{Grassland response to global change: SYMPHONY predictions}

In agreement with the $\mathrm{C}$ limitation of plants, elevated $\mathrm{CO}_{2}$ caused an increase in plant biomass and depositions of fresh organic C (Fig. 2). This stimulated the C-limited SOM decomposers, the degradation of SOM (PE), the release of mineral $\mathrm{N}$ and finally the biomass of N-limited SOM builders (data not shown) which sequester $\mathrm{C}$ and $\mathrm{N}$ in SOM. Thus, under elevated $\mathrm{CO}_{2}$, the bank mechanism limits (adjustment of SOM dynamics to $\mathrm{N}$ availability) the loss of SOM owing to PE. However, despite the bank mechanism, the compartments of mineral $\mathrm{N}$ and plant at steady state were higher under elevated compared with ambient $\mathrm{CO}_{2}$ (Fig. 2). As a result, ecosystem $\mathrm{N}$ outputs through leaching and plant exportation increased under elevated $\mathrm{CO}_{2}$. Mechanically, these increased $\mathrm{N}$ outputs led to decrease in the SOM builders/SOM decomposers ratio (Fig. 2; Table 3 for mechanistic understanding) decelerating $\mathrm{C}$ and $\mathrm{N}$ sequestration in SOM under elevated $\mathrm{CO}_{2}$ (Fig. 2).

The mathematical analysis of SYMPHONY indicated that the negative effect of elevated $\mathrm{CO}_{2}$ on $\mathrm{SOM}$ accumulation is general to all C-limited ecosystems (scenario 7). Indeed, SOM dynamics after replacement of variables by their expressions at steady state reads as follows:

$$
\left(\frac{\mathrm{d} C_{\mathrm{s}}}{\mathrm{d} t}\right)^{*}=\frac{1}{x}\left(z-\frac{k C_{\mathrm{a}}}{m_{\mathrm{p}}+r_{\mathrm{p}}+e_{\mathrm{p}}} * w\right)
$$

where

$$
\begin{gathered}
x=(s+r-A)\left(\frac{l}{i}(\alpha s-\beta(s+r))\right)+\frac{\alpha r A}{s+r-A} \\
z=\varphi_{\mathrm{i}} r A \\
w=\alpha(A-s) m_{\mathrm{p}}\left(\frac{l}{i}(\alpha s-\beta(s+r))\right)+\beta e_{\mathrm{p}} r A
\end{gathered}
$$

Given the conditions of feasibility of scenario 7, values of $x, z$, and $w$ are strictly positive. Thus, an increase in the concentration of $\mathrm{CO}_{2}\left(C_{\mathrm{a}}\right)$ has always a negative effect on the SOM pool Eqn (27).

In agreement with the bank mechanism described in scenarios 7 and 8, SYMPHONY predicted that increased $\mathrm{N}$ deposition ( $+30 \mathrm{~kg} \mathrm{~N}$ ha $^{-1} \mathrm{yr}^{-1}$ ) increases the $C_{\mathrm{df}} / C_{\mathrm{ds}}$ ratio and the rate of soil $C$ storage (Fig. 3 ). However, increased $\mathrm{N}$ deposition also increased the mineral $\mathrm{N}$ pool (Fig. 3) and thereby $\mathrm{N}$ leaching (results 

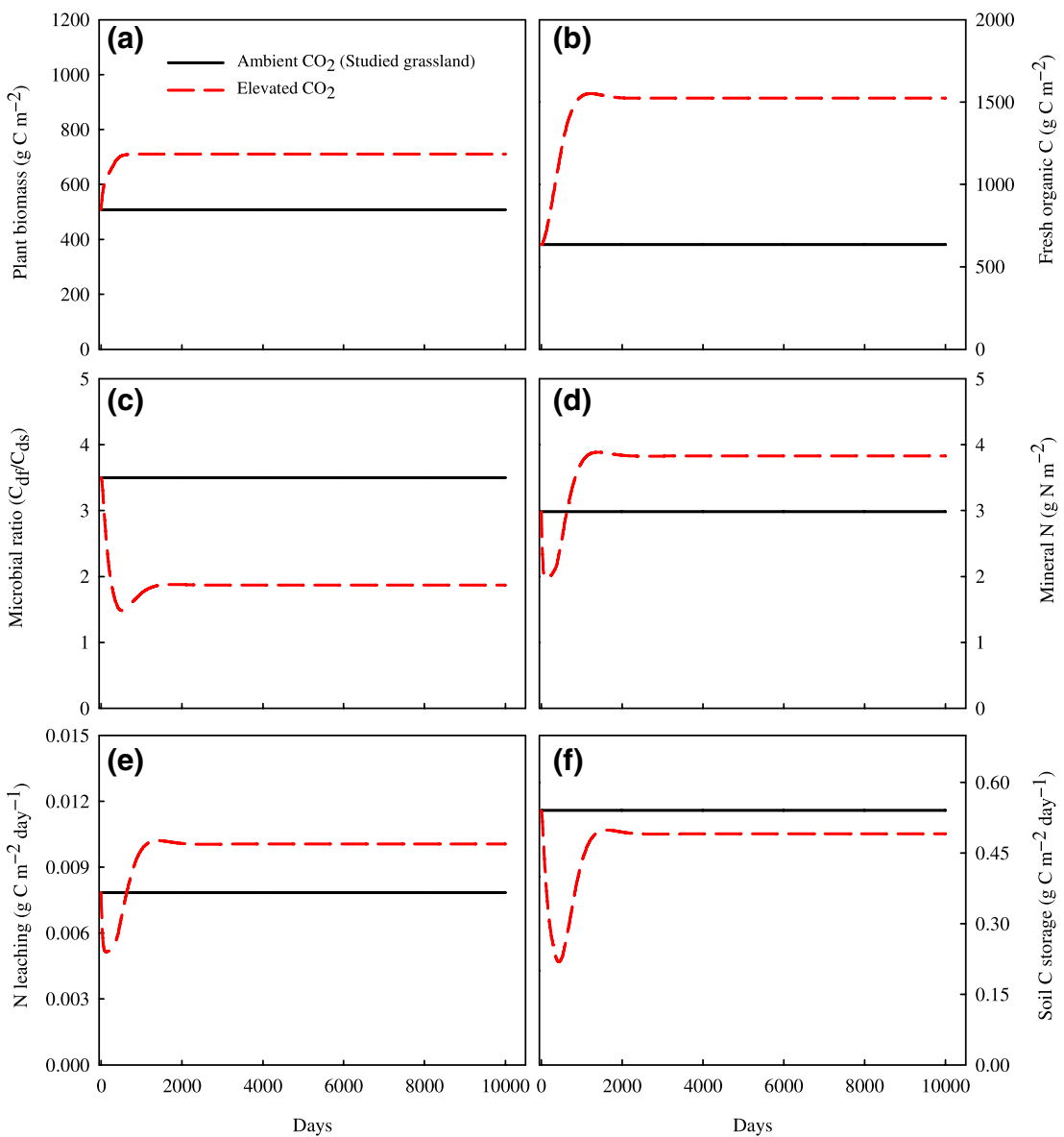

Fig. 2 Effects of $\mathrm{CO}_{2}$ on plant biomass (a), fresh organic C (b), SOM-builders/SOM-decomposers ratio $\left(C_{\mathrm{df}} / C_{\mathrm{ds}}\right)(\mathrm{c})$, mineral $\mathrm{N}(\mathrm{d}), \mathrm{N}$ leaching (e) and soil $\mathrm{C}$ storage (f). Solid black lines represent data from the study intensive pasture at ambient $\mathrm{CO}_{2}(400 \mathrm{ppm})$, while dashed red lines represent model simulations at elevated $\mathrm{CO}_{2}(560 \mathrm{ppm})$.

not shown), signifying that only a fraction of added $\mathrm{N}$ was sequestered with $\mathrm{C}$ in SOM. Moreover, $\mathrm{N}$ inputs to the ecosystem should not exceed the maximum capacity of SOM builders to sequester $\mathrm{N}$ in SOM (see conditions of feasibility of scenario 7); otherwise, the excess of $\mathrm{N}$ is leached and SOM accumulation becomes C-limited.

\section{Discussion}

\section{Paradox of plant persistence in a nutrient-trapping} environment

One major outcome of our modeling analyses is that the question of plant persistence is not trivial in an environment where $\mathrm{N}$ is sequestered owing to SOM accumulation (Syers et al., 1970; Schlesinger, 1990) and ecosystem $\mathrm{N}$ inputs/outputs are large compared to plant biomass. In an environment characterized by $\mathrm{N}$ sequestration, plants can survive only if $\mathrm{N}$ sequestration stops when mineral $\mathrm{N}$ availability becomes critical for plants or if the external $\mathrm{N}$ supply compensates for
$\mathrm{N}$ sequestration and eventual plant $\mathrm{N}$ exports. However, this latter condition is not realistic because $\mathrm{N}$ inputs to the ecosystem are not always higher than $\mathrm{N}$ removal by plant harvest/grazing and SOM accumulation (Vitousek \& Howarth, 1991; Rasmussen et al., 1998). Moreover, it has been shown that SOM is a nutrient source for plants when there is net $\mathrm{N}$ output from ecosystems (Kofoed \& Nemming, 1976; Dyke et al., 1983; Mattsson, 1987b; Rasmussen et al., 1998). These observations combined with our modeling results suggest the existence of a fine adjustment of soil $\mathrm{N}$ dynamics to plant $\mathrm{N}$ uptake allowing plant/microbe coexistence.

\section{Priming effect and microbial diversity in ecosystem functioning}

Among the twelve analyzed scenarios, only scenarios 7 and 8 of the SYMPHONY model were able to account for the four criteria of model evaluation: plant decomposers coexistence, ecosystem resistance to a long-term net $\mathrm{N}$ output from the ecosystems, the long-term SOM 


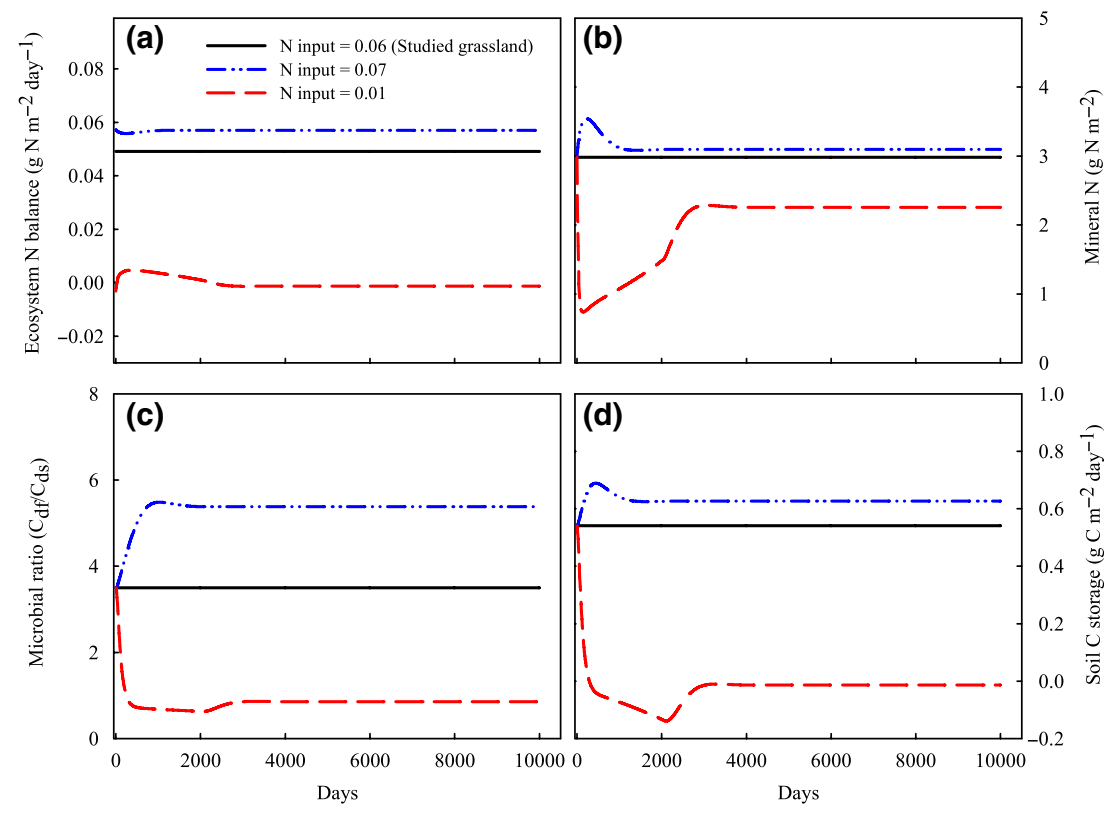

Fig. 3 Effects of $\mathrm{N}$ inputs on ecosystem $\mathrm{N}$ balance (a), mineral $\mathrm{N}(\mathrm{b}), \mathrm{SOM}$-builders/SOM-decomposers ratio $\left(C_{\mathrm{df}} / C_{\mathrm{ds}}\right)(\mathrm{c})$, and soil $\mathrm{C}$ storage (d). Solid black lines represent data from the study-intensive pasture where $\mathrm{N}$ inputs to the ecosystem are $0.06 \mathrm{~g} \mathrm{~N} \mathrm{~m}^{-2} \mathrm{day}^{-1}$. Dashed red lines represent the model simulations when $\mathrm{N}$ input to ecosystem is reduced to $0.01 \mathrm{~g} \mathrm{~N} \mathrm{~m}^{-2}$ day $^{-1}$. These two contrasted $\mathrm{N}$ treatments were used to analyze the mechanistic basis of bank functioning of soil. Blue dash-dot-dot lines represent the model simulations when $\mathrm{N}$ input to ecosystem is increased from 0.06 to $0.07 \mathrm{~g} \mathrm{~N} \mathrm{~m}^{-2}$ day $^{-1}$ to simulate enhanced atmospheric $\mathrm{N}$ depositions.

accumulation when there is net $\mathrm{N}$ input to the ecosystem and eventual steady state of SOM pool. This accounting is permitted by the fine adjustment of microbial $\mathrm{N}$ mineralization to plant $\mathrm{N}$ uptake the socalled 'bank mechanism.' Any excess of mineral nutrients is stored in SOM avoiding nutrient leaching, whereas mineral nutrients are released from SOM when they are in low concentration and could threaten plant persistence. A simple way to model this bank mechanism is to consider the destruction of SOM through PE and the interactions between two key microbial functional groups (Fontaine et al., 2003): SOM decomposers and SOM builders. These results support the idea of Fontaine and Barot (2005) that microbial diversity has key role on ecosystem persistence and properties as crucial as SOM accumulation. However, we cannot exclude the possibility of other model formulations able to simulate the bank mechanism with a single microbial type, but with more complex feedback mechanisms.

A number of laboratory studies support the model formulation presented in this study to simulate the 'bank mechanism'. Indeed, $\mathrm{N}$ availability drives the structure of soil microbial communities (Allison et al., 2008; Ramirez et al., 2010, 2012; Bates et al., 2011), the activity of enzymes degrading recalcitrant SOM (Carreiro et al., 2000; Ramirez et al., 2012), the intensity of PE (Fontaine et al., 2004; Blagodatskaya et al., 2007;
Fontaine et al., 2011) and thereby the direction of SOM pool change (increasing or decreasing). Now, the bank mechanism may be studied in detail in plant/soil experiments where SOM dynamics, $\mathrm{C}$ and $\mathrm{N}$ fluxes and structure of microbial communities could be determined by combining different methods such as the ${ }^{13} \mathrm{C}$ and ${ }^{15} \mathrm{~N}$ labeling of plants and mineral $\mathrm{N}$ (Recous et al., 1995; Dijkstra \& Cheng, 2007; Klumpp et al., 2009; Shahzad et al., 2012) and the pyrosequencing of microbial DNA (Wallenstein \& Weintraub, 2008; Pascault et al., 2013).

\section{Ecosystem response to global change: new predictions} lessen uncertainty

The earth's future climate depends on changes in ecosystem $\mathrm{C}$ storage in response to rising concentrations of atmospheric $\mathrm{CO}_{2}$. Current models qualitatively diverge in their predictions on ecosystem response to rising atmospheric $\mathrm{CO}_{2}$ (Amthor, 1995; Cao \& Woodward, 1998a,b; Kramer et al., 2002; Krinner et al., 2005). Some models focusing on the $\mathrm{C}$ cycle implicitly consider that plant growth is limited by $\mathrm{C}$ resources (Cao \& Woodward, 1998a; Krinner et al., 2005; Sokolov et al., 2008). These models consistently predict that an increase in atmospheric $\mathrm{CO}_{2}$ will stimulate primary production, $\mathrm{C}$ input to soil and in fine C storage in soil (Cao \& Woodward, 1998b; Krinner et al., 2005; Sokolov et al., 2008). 
According to these models, plants could slow down the increase in atmospheric $\mathrm{CO}_{2}$ emissions and the subsequent global warming. In contrast, the models considering the coupling between $\mathrm{C}$ and nutrient cycles predict a negligible response of ecosystem to elevated $\mathrm{CO}_{2}$ owing to limitation of plant growth by nutrient availability in soil (Kirschbaum et al., 1998; Sokolov et al., 2008; Goll et al., 2012).

SYMPHONY takes into account the possibility of $\mathrm{C}$ and $\mathrm{N}$ limitations of plants. It also considers changes in microbial activity and SOM mineralization induced by fresh $\mathrm{C}$ supply of plants grown under elevated $\mathrm{CO}_{2}$. The model predicts that an increase in atmospheric $\mathrm{CO}_{2}$ will not affect primary production and soil C storage when plants are $\mathrm{N}$-limited (i.e., high plant $\mathrm{N}$ uptake, low fertilization, high $\mathrm{N}$ exports and leaching). This prediction is supported by studies observing no effect of elevated $\mathrm{CO}_{2}$ in nutrient ( $\mathrm{N}$ or $\mathrm{P}$ ) limited grasslands and forests (Oren et al., 2001; Menge \& Field, 2007). When plants are C-limited (i.e., low plant $\mathrm{N}$ uptake, high fertilization, low $\mathrm{N}$ exports, and leaching), our model predicts an increase in primary production in response to rising atmospheric $\mathrm{CO}_{2}$. However, contrary to the forecasts of current models, our model indicates that a higher plant $C$ input to soil will deplete soil $\mathrm{C}$ stocks and increase $\mathrm{N}$ leaching as a result of SOM-decomposers stimulation (PE). This prediction is supported by recent studies showing a $\mathrm{CO}_{2}$-induced modification of soil microbial communities (Finzi et al., 2006; Carney et al., 2007; Blagodatskaya et al., 2010a) leading to an intensification of SOM mineralization (Körner \& Arnone, 1992; Finzi et al., 2006; Carney et al., 2007), a depletion in soil C stock (Carney et al., 2007) and an increase in $\mathrm{N}$ leaching (Liu et al., 2008).

Another outcome of our model was the positive effect of $\mathrm{N}$ inputs (i.e., fertilization, biological $\mathrm{N}$ fixation, and atmospheric depositions) on SOM accumulation and ecosystem $C$ storage irrespective of plant limitation ( $\mathrm{C}$ or $\mathrm{N}$ ) (Fig. 3). In the model, increased $\mathrm{N}$ availability not only stimulates photosynthesis of $\mathrm{N}$-limited plants but also shifts the soil microbial community from being dominated by SOM decomposers to SOM builders. This community change preserves the old pre-existing soil $\mathrm{C}$ and stimulates formation of new soil $\mathrm{C}$ leading to SOM accumulation. These predictions are consistent with studies showing an acceleration of SOM accumulation (Hagedorn et al., 2003; Bowden et al., 2004) by microbial communities with reduced catabolic capabilities in $\mathrm{N}$-amended ecosystems (Carreiro et al., 2000; Fontaine et al., 2004b; Allison et al., 2008; Ramirez et al., 2012). Finally, by injecting $\mathrm{N}$ into ecosystems, legumes can also increase the SOM-builders/ SOM-decomposers ratio explaining their positive effect on soil C sequestration (Sierra \& Nygren, 2005; Van Groenigen et al., 2006).

\section{Soil modeling: the slow revolution continues}

Current models of SOM dynamics are based on concepts developed seventy years ago (Jenny, 1941; Hénin \& Dupuis, 1945) simulating the SOM pool as a reservoir of water that flows out. This simple concept has generated models simulating $\mathrm{C}$ and $\mathrm{N}$ dynamics in a variety of ecosystem types, pedoclimatic situations, land use, and agricultural practices (Smith et al., 1997). Although this valuable legacy must be preserved and used by the scientific community, current models should also evolve to integrate new knowledge and social expectations. It is now clear that PE exerts a strong effect on SOM dynamics (Bingeman et al., 1953; Wu et al., 1993; Cheng et al., 2003; Fontaine et al., 2004a,b) with important consequences for ecosystem function and responses to global change (Hoosbeek et al., 2004; Dijkstra \& Cheng, 2007; Talhelm et al., 2009; Drake et al., 2011; Iversen et al., 2012). Ecosystem models thus need to incorporate PE mechanisms if they are to accurately simulate trajectories of plant production and soil C storage under future conditions.

One of the main reasons why PE is not yet integrated in current models is the lack of an example of plant/ soil models embedding PE and providing realistic predictions for key ecosystem functions. We contribute to filling this gap by proposing the first parameterized plant-soil model embedding the PE. With five compartments and eight parameters, the soil module of SYMPHONY is relatively simple and lies in the low range of model complexity (Smith et al., 1997). When tested on a permanent grassland, SYMPHONY provided realistic predictions for ecosystem compartments and key fluxes such as forage production, soil $\mathrm{C}$ storage and $\mathrm{N}$ leaching. SYMPHONY was also able to propose new predictions regarding the ecosystem response to elevated $\mathrm{CO}_{2}$ and increased $\mathrm{N}$ depositions. In particular, SYMPHONY may explain the stimulation of soil $\mathrm{C}$ mineralization (PE) induced by enhanced fresh $\mathrm{C}$ input in ecosystems exposed to elevated $\mathrm{CO}_{2}$ (Carney et al., 2007; Phillips et al., 2012). This stimulation may be responsible for a positive feedback on atmospheric $\mathrm{CO}_{2}$ concentration and climate. Collectively, these results suggest that the mathematical representation of PE proposed in SYMPHONY may be incorporated in current ecosystem models with few additional parameters, improving accuracy of predictions.

Future works could test the behavior of SYMPHONY in other ecosystems and climates in order to determine the generality of our predictions. SYMPHONY could also be used to answer further scientific questions. 
Given that SYMPHONY integrates the role of two key microbial populations on SOM dynamics it can be used to model effects of an erosion of soil biodiversity on cultivated soil functioning. It may also suggest alternative agricultural practices that will optimize the fine adjustment of $\mathrm{N}$ mineralization to plant $\mathrm{N}$ uptake, minimizing $\mathrm{N}$ losses and fertilizer application. These new investigations will require new development of SYMPHONY by including other soil processes and environmental factors (i.e. effect of temperature and water). However, a more efficient approach would be an inclusion of SYMPHONY in current models where it could benefit from the knowledge accumulated during more than 70 years of soil modeling.

\section{Acknowledgements}

This research was funded by the department of Écologie des forêts, prairies et milieux aquatiques (EFPA) of INRA, la Région Auvergne (CPER Environnement 2013), the Higher Education commission (HEC, Pakistan), the European Community's 7th framework under grant agreement no. 226701 (CARBOExtreme) and the INRA Meta program ACCAF ('Adaptation au Changement Climatique de l'Agriculture et de la Forêt'). The idea of this work originated from the consortia of researchers created by the project INRA-INRIA VITELBIO. This work is dedicated to Tahira PERVEEN and Muhammad HUSSAIN. We also thank our favorite native English speakerine Juliette Bloor for her corrections on the writing.

\section{References}

Allard V, Soussana JF, Falcimagne R et al. (2007) The role of grazing management for the net biome productivity and greenhouse gas budget $\left(\mathrm{CO}_{2}, \mathrm{~N}_{2} \mathrm{O}\right.$ and $\left.\mathrm{CH}_{4}\right)$ of semi-natural grassland. Agriculture, Ecosystems and Environment, 121, 47-58.

Allison SD, Czimczik CI, Treseder KK (2008) Microbial activity and soil respiration under nitrogen addition in Alaskan boreal forest. Global Change Biology, 14, 1156 1168.

Amthor JS (1995) Terrestrial higher plant response to increasing atmospheric $\left[\mathrm{CO}_{2}\right]$ in relation to the global carbon cycle. Global Change Biology, 1, 243-274.

Balesdent J, Derrien D, Fontaine S et al. (2011) Contribution de la rhizodeposition aux matières organiques du sol, quelques implications pour la modélisation de la dynamique du carbone. Etude et Gestion des Sols, 18, 201-216.

Barnola JM, Raynaud D, Neftel A, Oeschger $\mathrm{H}$ (1983) Comparison of $\mathrm{CO}_{2}$ measurements by two laboratories on air from bubbles in polar ice. Nature, 303, $410-413$.

Bates ST, Berg-Lyons D, Caporaso JG, Walters WA, Knight R, Fierer N (2011) Examining the global distribution of dominant archaeal populations in soil. ISME Journal, 5, 908-917.

Bingeman CW, Varner JE, Martin WP (1953) The effect of the addition of organic materials on the decomposition of an organic soil. Soil Science Society of America Journal, 17, 34-38.

Blagodatskaya E, Blagodatsky S, Anderson T, Kuzyakov Y (2007) Priming effects in Chernozem induced by glucose and $\mathrm{N}$ in relation to microbial growth strategies. Applied Soil Ecology, 37, 95-105.

Blagodatskaya E, Blagodatskaya S, Dorodnikov M, Kuzyakov Y (2010a) Elevated atmospheric $\mathrm{CO}_{2}$ increases microbial growth rates in soil: results of three $\mathrm{CO}_{2}$ enrichment experiments. Global Change Biology, 16, 836-848.

Blagodatskaya S, Blagodatskaya E, Yuyukina T, Kuzyakov Y (2010b) Model of apparent and real priming effects: linking microbial activity with soil organic matter decomposition. Soil Biology \& Biochemistry, 42, 1275-1283.

Bowden RD, Davidson E, Savage K, Arabia K, Steudler P (2004) Chronic nitrogen additions reduce total soil respiration and microbial respiration in temperate forest soils at the Harvard forest. Forest Ecology and Management, 196, 43-56.
Cao M, Woodward FI (1998a) Net primary and ecosystem production and carbon stocks of terrestrial ecosystems and their responses to climate change. Global Change Biology, 4, 185-198.

Cao M, Woodward FI (1998b) Dynamic responses of terrestrial ecosystem carbon cycling to global climate change. Nature, 393, 249-252.

Carney KM, Hungate BA, Drake BG, Megonigal JP (2007) Altered soil microbial community at elevated $\mathrm{CO} 2$ leads to loss of soil carbon. Proceedings of the National Academy of Sciences of the United States of America, 104, 4990-4995.

Carreiro MM, Sinsabaugh RL, Repert DA, Parkhurst DF (2000) Microbial enzyme shifts explain litter decay responses to simulated nitrogen deposition. Ecology, 81, 2359-2365.

Cheng WX, Johnson DW, Fu SL (2003) Rhizosphere effects on decomposition: controls of plant species, phenology, and fertilization. Soil Science Society of America Journal, 67, 1418-1427.

Dijkstra FA, Cheng W (2007) Interactions between soil and tree roots accelerate longterm soil carbon decomposition. Ecology Letters, 10, 1046-1053.

Dijkstra FA, Bader NE, Johnson DW, Cheng W (2009) Does accelerated soil organic matter decomposition in the presence of plants increase plant $\mathrm{N}$ availability? Soil Biology and Biochemistry, 41, 1080-1087.

Dijkstra FA, Hutchinson GL, Reeder JD, LeCain DR, Morgan JA (2011) Elevated $\mathrm{CO}_{2}$ but not defoliation, enhances $\mathrm{N}$ cycling and increases short-term soil $\mathrm{N}$ immobilization regardless of $\mathrm{N}$ addition in a semiarid grassland. Soil Biology $\mathcal{E}$ Biochemistry, 43, 2247-2256.

Drake JE, Gallet-Budynek A, Hofmockel KS et al. (2011) Increases in the flux of carbon belowground stimulate nitrogen uptake and sustain the long-term enhancement of forest productivity under elevated $\mathrm{CO}_{2}$. Ecology Letters, 14, 349-357.

Dyke GV, George BJ, Johnston AE, Poulton PR, Todd AD (1983) The Broadbalk wheat experiment 1968-78: yields and plant nutrients in crops grown continuously and in rotation. Report for 1982, Rothamsted Experimental Station, Part 2, pp. 5-44.

Finzi AC, Sinsabaugh RL, Long TM, Osgood MP (2006) Microbial community responses to atmospheric carbon dioxide enrichment in a warm-temperate forest. Ecosystems, 9, 215-226.

Fontaine S, Barot S (2005) Size and functional diversity of microbe populations control plant persistence and long-term soil carbon accumulation. Ecology Letters, 8 $1075-1087$

Fontaine S, Mariotti A, Abbadie L (2003) The priming effect of organic matter: a question of microbial competition? Soil Biology \& Biochemistry, 35, 837-843.

Fontaine S, Bardoux G, Benest D, Verdier B, Mariotti A, Abbadie L (2004a) Mechanisms of the priming effect in a savannah soil amended with cellulose. Soil Science Society of America Journal, 68, 125-131.

Fontaine S, Bardoux G, Abbadie L, Mariotti A (2004b) Carbon input to soil may decrease soil carbon content. Ecology Letters, 7, 314-320.

Fontaine S, Barot S, Barre P, Bdioui N, Mary B, Rumpel C (2007) Stability of organic carbon in deep soil layers controlled by fresh carbon supply. Nature, 450, 277-280.

Fontaine S, Henault C, Aamor A et al. (2011) Fungi mediate long term sequestration of carbon and nitrogen in soil through their priming effect. Soil Biology $\mathcal{E}$ Biochemistry, 43, 86-96.

Gignoux J, House J, Hall D, Masse D, Nacro HB, Abbadie L (2001) Design and test of a generic cohort model of soil organic matter decomposition: the SOMKO model. Global Ecology and Biogeography, 10, 639-660.

Goll DS, Brovkin V, Parida BR et al. (2012) Nutrient limitation reduces land carbon uptake in simulations with a model of combined carbon, nitrogen and phosphorus cycling. Biogeosceinces, 9, 3547-3569.

Guenet B, Neill C, Bardoux G, Abbadie L (2010) Is there a linear relationship between priming effect intensity and the amount of organic matter input? Applied Soil Ecology, 46, 436-442.

Hagedorn F, Spinnler D, Siegwolf R (2003) Increased N deposition retards mineralization of old soil organic matter. Soil Biology \& Biochemistry, 35, 1683-1692.

Heimann M, Reichstein M (2008) Terrestrial ecosystem carbon dynamics and climate feedbacks. Nature, 451, 289-292.

Hénin S, Dupuis M (1945) Essai de bilan de la matière organique du sol. Annales Agronomiques, 15, 17-29.

Hoosbeek MR, Lukac M, van Dam D et al. (2004) More new carbon in the mineral soil of a poplar plantation under Free Air Carbon Enrichment (POPFACE): cause of increased priming effect? Global Biogeochemical Cycles, 18, GB1040.

Inselsbacher E, Wanek W, Strauss J, Zechmeister-Boltenstern S, Müller C (2013) A novel ${ }^{15} \mathrm{~N}$ tracer model reveals: plant nitrate uptake governs nitrogen transformation rates in agricultural soils. Soil Biology \& Biochemistry, 57, 301-310.

Iversen CM, Keller JK, Garten CT, Norby RJ (2012) Soil carbon and nitrogen cycling and storage throughout the soil profile in a sweetgum plantation after 11 years of CO2-enrichment. Global Change Biology, 18, 1684-1697. 
Jenny H (1941) Factors of Soil Formation. A System of Quantitative Pedology. McGrawHill Book Company, New York, NY, USA.

Johnston AE, Poulton PR, Coleman K (2009) Soil organic matter: its importance in sustainable agriculture and carbon dioxide fluxes. In: Advances in Agronomy, Vol 101 (ed. Sparks DS), pp. 1-57. Academic Press, Burlington.

Keeney DR, Hatfield JL (2008) The nitrogen cycle, historical perspective, and current and potential future concerns. In: Nitrogen in the Environment Sources, Problems and Management (eds Hatfield JL, Follett RF), pp. 1-18. Academic Press, New York, NY, USA

Kirkby CA, Richardson AE, Wade LJ, Batten GD, Blanchard C, Kirkegaard JA (2013) Carbon-nutrient stoichiometry to increase soil carbon sequestration. Soil Biology $\mathcal{E}$ Biochemistry, 60, 77-86.

Kirschbaum MUF, Medlyn BE, King DA et al. (1998) Modelling forest-growth response to increasing $\mathrm{CO}_{2}$ concentration in relation to various factors affecting nutrient supply. Global Change Biology, 4, 23-41.

Klumpp K, Fontaine S, Attard E, Le Roux X, Gleixner G, Soussana JF (2009) Grazing triggers soil carbon loss by altering plant roots and their control on soil microbial community. Journal of Ecology, 97, 876-885.

Klumpp K, Tallec T, Guix N, Soussana JF (2011) Long-term impacts of agricultural practices and climatic variability on carbon storage in a permanent pasture. Global Change Biology, 17, 3534-3545.

Knops JH, Tilman D (2000) Dynamics of soil nitrogen and carbon accumulation for 61 years after agricultural abandonment. Ecology, 81, 88-89.

Kofoed AD, Nemming O (1976) Askov 1894 - fertilizers and manure on sandy and loamy soils. Annales Agronomiques, 27, 583-610.

Körner C, Arnone JA III (1992) Responses to elevated carbon dioxide in artificial tropical ecosystems. Science, 257, 1672-1675.

Kramer K, Leionen I, Bartelink HH et al. (2002) Evaluation of six process-based forest growth models using eddy-covariance measurements of $\mathrm{CO}_{2}$ and $\mathrm{H}_{2} \mathrm{O}$ fluxes at six forest sites in Europe. Global Change Biology, 8, 213-230.

Krinner G, Viovy N, de Noblet-Ducoudre N et al. (2005) A dynamic global vegetation model for studies of the coupled atmosphere-biosphere system. Global Biogeochemical Cycles, 19, GB 1015.

Kuzyakov Y, Friedel JK, Stahr K (2000) Review of mechanisms and quantification of priming effects. Soil Biology \& Biochemistry, 32, 1485-1498.

Liu JX, Zhang DQ, Zhou GY, Faivre-Vuillin B, Deng Q, Wang CL (2008) $\mathrm{CO}_{2}$ enrichment increases $\mathrm{N}$ leaching from model forest ecosystems in subtropical China. Biogeoscience, 5, 1783-1795.

Loiseau P, Soussana JF (1999) Elevated $\left[\mathrm{CO}_{2}\right]$, temperature increase and N supply effects on the accumulation of below-ground carbon in a temperate grassland ecosystem. Plant and Soil, 212, 123-134.

Lord EI, Anthony SG, Goodlass G (2002) Agricultural nitrogen balance and water quality in the UK. Soil Use and Management, 18, 363-369.

Martel YA, Paul EA (1974) The use of radiocarbon dating of organic matter in the study of soil genesis. Soil Science Society of America Journal, 38, 501-506.

Mary B, Recous S, Darwis D, Robin D (1996) Interactions between decomposition of plant residues and nitrogen cycling in soil. Plant and Soil, 181, 71-82.

Mattsson L (1987a) 4 Swedish Long-Term Experiments with N, P and K.1. Yield Results. Swedish Journal of Agricultural Research, 17, 153-160.

Mattsson L (1987b) 4 Swedish Long-Term Experiments with N, P and K.2. Soil Data and Plant Nutrient Balances. Swedish Journal of Agricultural Research, 17, 161-167.

McGill WB (1996) Review and classification of ten soil organic matter (SOM) models In: Evaluation of Soil Organic Matter Models (eds Powlson DS, Smith P, Smith JU), pp. 111-132. Springer, Berlin; New York, NY, USA.

Menge DNL, Field CB (2007) Simulated global changes alter phosphorus demand in annual grassland. Global Change Biology, 13, 2582-2591.

Neill C, Gignoux J (2006) Soil organic matter decomposition driven by microbial growth: a simple model for a complex network of interactions. Soil Biology $\mathcal{E}$ Biochemistry, 38, 803-811.

Neill C, Guenet B (2010) Comparing two mechanistic formalisms for soil organic dynamics: a test with in vitro priming effect observations. Soil Biology $\mathcal{E}$ Biochemistry, 42, 1212-1221.

Nguyen C (2003) Rhizodeposition of organic C by plant: mechanisms and control. Agronomie, 23, 375-396.

Nottingham AT, Griffiths H, Chamberlain PM, Stott AW, Tanner EVJ (2009) Soil priming by sugar and leaf-litter substrates: a link to microbial groups. Applied Soil Ecology, 42, 183-190.

Oren R, Ellsworth DS, Johnsen KH et al. (2001) Soil fertility limits carbon sequestration by forest ecosystems in a $\mathrm{CO}_{2}$-enriched atmosphere. Nature, 411, 469-472.

Pascault N, Ranjard L, Kaisermann A et al. (2013) Stimulation of different functional groups of bacteria by various plant residues as a driver of soil priming effect. Ecosystems, 16, 810-822.
Paul EA, Clark FE (1989) Soil Microbiology and Biochemistry. Academic Press, San Diego, CA, USA.

Phillips RP, Meier IC, Bernhardt ES, Grandy AS, Wickings K, Finzi AC (2012) Roots and fungi accelerate carbon and nitrogen cycling in forests exposed to elevated $\mathrm{CO}_{2}$. Ecology Letters, 15, 1042-1049.

Picon-Cochard C, Pilon R, Tarroux E, Pagès L, Robertson J, Dawson L (2012) Effect of species, root branching order and season on the root traits of 13 perennial grass species. Plant and Soil, 353, 47-57.

Ramirez KS, Lauber CL, Knight R, Bradford MA, Fierer N (2010) Consistent effects of nitrogen fertilization on soil bacterial communities in contrasting systems. Ecology, 91, 3463-3470.

Ramirez KS, Craine JM, Fierer N (2012) Consistent effects of nitrogen amendments on soil microbial communities and processes across biomes. Global Change Biology, 18 1918-1927.

Rasmussen PE, Goulding KWT, Brown JR, Grace PR, Janzen HH, Korschens M (1998) Agroecosystem-Long-term agroecosystem experiments: assessing agricultural sustainability and global change. Science, 282, 893-896.

Recous S, Robin D, Darwis D, Mary B (1995) Interactions between decomposition of plant residues and nitrogen cycling in soil. Soil Biology \& Biochemistry, 27, 1529-1538.

Recous S, Loiseau P, Machet JM, Mary B (1996) Transformations et devenir de l'azote de l'engrais sous cultures annuelle et sous prairies. In: Maitrise de l'azote dans les agrosystèmes (eds Lemaire G, Nicolardot B), pp. 201-216. INRA, Paris.

Reichstein M, Árgen GI, Fontaine S (2009) Is there a theoretical limit to soil carbon storage in old-growth forests? A model analysis with contrasting approaches. In Old-Growth Forests (eds Wirth C, Gleixner G, Heimann M), pp. 267-281. Springer, Berlin Heidelberg

Sanderman J, Amundson RG, Baldocchi DD (2003) Application of eddy covariance measurements to the temperature dependence of soil organic matter mean residence time. Global Biogeochemical Cycles, 17, 1029. doi:10/2001GB001833.

Schimel JP, Weintraub MN (2003) The implications of exoenzyme activity on microbial carbon and nitrogen limitation in soil: a theoretical model. Soil Biology $\mathcal{E}$ Biochemistry, 35, 549-563.

Schlesinger WH (1990) Evidence from chronosequence studies for a low carbon-storage potential of soils. Nature, 348, 232-234.

Shahzad T, Chenu C, Repincay C, Mougin C, Ollier JL, Fontaine S (2012) Plant clipping decelerates the mineralization of recalcitrant soil organic matter under multiple grassland species. Soil Biology \& Biochemistry, 51, 73-80.

Sierra J, Nygren P (2005) Role of root inputs from a dinitrogen-fixing tree in soil carbon and nitrogen sequestration in a tropical agroforestry system. Australian Journal of Soil Research, 43, 667-675.

Simon JC, Peyraud JL, Decau ML, Delaby L, Vertes F, Delagarde R (1996) Gestion de l'azote dans les systèmes prairiaux pâturés permanentes ou de longe durée. In Maîtrise de l'azote dans les agrosystèmes (eds Lemaire G, Nicolardot B), pp. 201-216. INRA, Paris.

Smith P, Smith JU, Powlson DS et al. (1997) A comparison of the performance of nine soil organic matter models using datasets from seven long-term experiments. Geoderma, 81, 153-225.

Sokolov AP, Kicklighter DW, Melillo JM, Felzer BS, Schlosser CA, Cronin TW (2008) Consequences of considering carbon-nitrogen interactions on the feedbacks between climate and the terrestrial carbon cycle. Journal of Climate, 21, 3776-3796.

Syers JK, Adams JA, Walker TW (1970) Accumulation of organic matter in a chronosequence of soils developed on wind-blown sand in New Zealand. European Journal of Soil Science, 21, 146-153.

Talhelm AF, Pregitzer KS, Zak DR (2009) Species-specific responses to atmospheric carbon dioxide and tropospheric ozone mediate changes in soil carbon. Ecology Letters, 12, 1219-1228.

Van Groenigen KJ, Six J, Hungate BA, de Graaff MA, van Breemen N, van Kessel C (2006) Element interactions limit soil carbon storage. Proceedings of the National Academy of Sciences of the United States of America, 103, 6571-6574.

Vitousek PM, Howarth RW (1991) Nitrogen limitation on land and in the sea - how can it occur. Biogeochemistry, 13, 87-115.

Wallenstein MD, Weintraub MN (2008) Emerging tools for measuring and modelling the in situ activity of soil extracellular enzymes. Soil Biology \& Biochemistry, 40, 2098-2106.

Wu J, Brookes PC, Jenkinson DS (1993) Formation and destruction of microbial biomass during the decomposition of glucose and ryegrass in soil. Soil Biology $\mathcal{E}$ Biochemistry, 25, 1435-1441

Wutzler T, Reichstein M (2008) Colimitation of decomposition by substrate and decomposers - a comparison of model formulations. Biogeosciences, 5, 749-759. 


\section{Supporting Information}

Additional Supporting Information may be found in the online version of this article:

Appendix S1. Mathematical analysis of models when decay rate of $C_{\mathrm{s}}$ is limited by the amount of $C_{\mathrm{s}}$. Appendix S2. Analysis of switch between scenarios $7 \& 8$ of SYMPHONY model.

Appendix S3. Matrix analysis of SYMPHONY model parameterized with the study grasslands. 